\title{
Glauconitic laminated crusts from hydrothermal alteration of Jurassic pillow-lavas (Betic Cordillera, S Spain): a microbial influence case
}

\author{
M. Reolid*, I. Abad \\ Departamento de Geología and Centro de Estudios Avanzados en Ciencias de la Tierra, Universidad de Jaén, \\ Campus Las Lagunillas sn, 23071 Jaén, Spain \\ e-mail addresses: mreolid@ujaen.es (M.R., *corresponding author); miabad@ujaen.es (I.A.)
}

Received: 28 August 2013 / Accepted: 24 April 2014 / Available online: 30 October 2014

\begin{abstract}
The green crusts infilling the spaces among pillow-lavas from the Lower Jurassic Median Subbetic (Betic Cordillera, S Spain) are the subject of this textural, mineralogical and geochemical study. Their exceptional laminated morphology and mineral composition made it possible to establish the genetic conditions and different phases of the infilling, while also interpreting the possible influence of microbial activity in the origin and growth of the laminated crusts. Two types of crust were discerned: green laminated crusts and black crusts. The green crusts are mostly composed by glauconite and celadonite, and a minority by smectites, whereas black crusts and lens-shaped nappes are saponitic. The record of filaments and coccoid-shaped forms at different scales from the glauconitic crusts indicates the potential implication of chemoorganotrophic microbes in the precipitation of the glauconite, and the development of laminated textures under lowtemperature hydrothermal conditions. During an early stage, alteration of pillow-lava margins caused by hydrothermal reducing fluids resulted in black films of saponite and calcite filling the void spaces. During a cooling phase, green laminated crusts composed by glauconite and celadonite grew under oxic conditions due to both circulation and diffusion of oxygenated sea-water along inter-pillow spaces, and the chemoorganotrophic microbial activity. A new stage of saponite formation with calcite occurred under higher T and confined/reducing conditions resulting from deposition of marine sediments; finally, calcite and quartz crystallised as the latest product closing the remaining space (or producing geodes) among the pillow-lava bodies.
\end{abstract}

Keywords: Celadonite, Glauconite, Saponite, Hydrothermal, Microbes, Lower Jurassic

\section{Resumen}

Las costras verdes localizadas entre las lavas almohadilladas del Subbético Medio (Cordillera Bética, S España) presentan una morfología laminada excepcional. La caracterización textural, geoquímica y mineralógica de estas costras ha permitido establecer las condiciones bajo las que se formaron e interpretar la posible influencia de la actividad microbiana en el origen, crecimiento y morfología de las mismas. Se han diferenciado dos tipos de costras: costras laminadas verdes y costras negras. Las costras verdes están formadas mayoritariamente por glauconita y celadonita y, en menor proporción, por esmectitas. Las costras negras, sin embargo, son de naturaleza saponítica. La presencia de filamentos y formas cocoidales a diferentes escalas de observación en las costras verdes, sugiere la mediación de microbios quimiorganotróficos en la precipitación de la glauconita así como en el desarrollo de texturas laminadas en un ambiente hidrotermal de baja temperatura. En un primer momento, la alteración de las superficies de las lavas almohadilladas, bajo la influencia de fluidos hidrotermales de carácter reductor que siguieron al depósito de las lavas almohadilladas, produjo láminas negras de saponita y calcita. En una fase de enfriamiento posterior, bajo condiciones oxidantes favorecidas por la circulación y difusión de agua marina oxigenada a lo largo de los huecos entre las lavas almohadilladas y con la participación de actividad microbiana quimiorganotrófica, tuvo lugar la precipitación de glauconita y celadonita generando las costras verdes laminadas. Como consecuencia del enterramiento de la pila volcánica debido al depósito de sedimentos marinos, se produjo una confinación del medio que favoreció el incremento de temperatura y un ambiente reductor que propició nuevamente la génesis de saponita y calcita. Finalmente, en el hueco entre las lavas cristalizó calcita y cuarzo, que en algunos casos dieron lugar a geodas y en otros al cierre total del espacio entre las mismas.

Palabras clave: Celadonita, Glauconita, Saponita, Hidrotermal, Microbios, Jurásico inferior

\section{Introduction}

Glauconitic micas related to volcanic and hydrothermal processes are scarcely documented in the literature (Buatier et al., 1989, 1993; Alt et al., 1992; Clayton and Pearce, 2000; Ionescu et al., 2006; Clauer et al., 2011) with respect 
to glauconitic facies from sedimentary environments (e.g. Porrenga, 1967; Odin and Letolle, 1980; Odin and Matter, 1981; Bornhold and Giresse, 1985; Odin and Fullagar, 1988; Amorosi, 1995; Jiménez-Millán et al., 1998; Eder et al., 2007; Sánchez-Navas et al., 2008; Baldermann et al., 2013). In both cases — volcanic-hydrothermal and sedimentary-diagenetic - glauconite, a Fe- and K-rich mica structure mineral (Odin and Matter, 1981), is mainly recorded as peloidal grains. This research provides a very different texture of glauconitic micas forming laminated crusts associated with spaces between pillow-lava bodies.

Jurassic pillow-lavas, intercalated between pelagic sediments, have been studied by numerous authors in the Median Subbetic domain of the External Zones of the Betic Cordillera (Southern Spain) (Comas et al., 1986; Puga et al., 1988, 1989; Portugal et al., 1995; Morata et al., 1996; Vera et al., 1997). These submarine volcanic rocks are held to be related to an extensional process of crustal thinning. The intrusion of volcanic and subvolcanic bodies in the Subbetic Zone during the Jurassic generated hydrothermal systems that produced intense alteration of the igneous and sedimentary host materials. The processes of fluid-rock interaction caused the formation of phyllosilicates filling the network of veins and fractures (Abad et al., 2003; Jiménez-Millán et al., 2008).

In this study we describe and analyse the morphology and composition of the vein minerals associated with spaces among the pillow-lava bodies, which are composed mainly by greenish phyllosilicates, quartz and calcite. Samples were characterised using a variety of techniques, including powder X-ray diffraction, petrographic microscopy, scanning and transmission electron microscopy, electron microprobe, and X-ray fluorescence. Results on the morphology and microstructure of the glauconitic crusts provide a basis for the discussion of a possible influence of microbial activity on the origin and growth of the crusts.

\section{Geological setting}

The Betic Cordillera (Southern Spain) is the westernmost European chain related to the Alpine orogeny. The External Zones of this cordillera (Prebetic and Subbetic) are constituted mainly by sedimentary marine deposits deposited in the Southern Iberian Palaeomargin from the Triassic to the Miocene. During the early-late Jurassic in the Southern Iberian Palaeomargin there was an intense submarine volcanic activity in wide sectors of the pelagic basin. The analysed pillow-lava outcrops come from the Jurassic submarine volcanic rocks of the Median Subbetic palaeogeographic unit. These volcanic rocks have a WSW-ENE orientation, and are $5-10 \mathrm{~km}$ wide and around $250 \mathrm{~km}$ long. Basaltic pillow-lava flows dominate, interbedded with pyroclastic rocks and pelagic sediments. The maximum thickness of these volcanic rocks, described in the literature, is over $300 \mathrm{~m}$ (Vera et al., 1997). The Lower Jurassic submarine volcanic rocks of the
Median Subbetic are considered as transitional alkaline, originated in an extensional process of crustal thinning (Portugal et al., 1995; Vera et al., 1997).

The Campotéjar outcrop (coordinates 37030'12"N, $\left.3^{\circ} 37^{\prime} 50^{\prime \prime} \mathrm{W}\right)$ is located close to the motorway joining the cities of Jaén and Granada, at km 79 (Granada province) (Fig. 1a). Pillow-lava bodies are well exposed in the talus of the highway (Fig. 1b). In the case studied here, voids among the pillows are commonly filled with a variety of material, including broken-up fragments of glassy-lava, sediment materials (limestones, marls) and secondary vein minerals. The studied clay minerals were obtained from the veins (Fig. 1b).

Previous works investigated the petrology and geochemistry of these volcanic rocks (Comas et al., 1986; Puga et al., 1988, 1989; Portugal et al., 1995; Morata et al., 1996). The main minerals in the pillow-lava are olivine (varies between chrysolite to hyalosiderite), Ti-augite, plagioclase (variable from bytownite to oligoclase) and minoritary biotite, Ti-hornblende, apatite and Fe-Ti oxides (Puga et al., 1989; Morata et al., 1996).

\section{Methods}

Petrographic microscope, in addition to magnifying binocular glasses, were used to determine the morphology of the crusts on 15 thin sections and 13 polished slabs. Whole-rock samples were studied using a Philips PW 1710 powder diffractometer with $\mathrm{CuK} \alpha$ radiation, a graphite monochromator and an automatic divergence slit at the Instituto Andaluz de Ciencias de la Tierra (IACT, Granada). Oriented aggregates were prepared by sedimentation on glass slides. Ethylene glycol (EG) treatment was carried out on the aggregates to corroborate the identification of smectites on the basis of the expandability of these phases.

Following the XRD and optical study, carbon-coated polished thin sections were examined by Scanning Electron Microscopy (SEM) with an energy dispersive X-ray spectroscopy (EDX) microanalyser, and analysed with an Electron Microprobe (EMPA). Observations using back-scattered electron (BSE) imaging were carried out with a Merlin Carl Zeiss SEM in the Centro de Instrumentación Científico-Técnica of the Universidad de Jaén (Spain) and a Leo 1430-VPSEM at the Centro de Instrumentación Científica (CIC) of the Universidad de Granada. An accelerating voltage of $20 \mathrm{kV}$, with a beam current of 1-2 $\mathrm{nA}$, and counting time of $50 \mathrm{~s}$, were used to analyse the silicates by SEM, using the following standards: albite $(\mathrm{Na})$, periclase $(\mathrm{Mg})$, wollastonite $(\mathrm{Si}$ and $\mathrm{Ca})$, and orthoclase $(\mathrm{K})$, and synthetic $\mathrm{Al}_{2} \mathrm{O}_{3}(\mathrm{Al}), \mathrm{Fe}_{2} \mathrm{O}_{3}(\mathrm{Fe})$ and $\mathrm{MnTiO}_{3}$ ( $\mathrm{Ti}$ and $\mathrm{Mn}$ ). In addition, the green laminated crusts were split and pieces from the inner surfaces of the crusts were mounted, coated with gold, and examined under the SEM with secondary electrons to study the crystal morphology. The equipments used were a SCI Quanta 400 and a FEG Zeiss Auriga at the CIC. Microprobe analyses of phyllosili- 

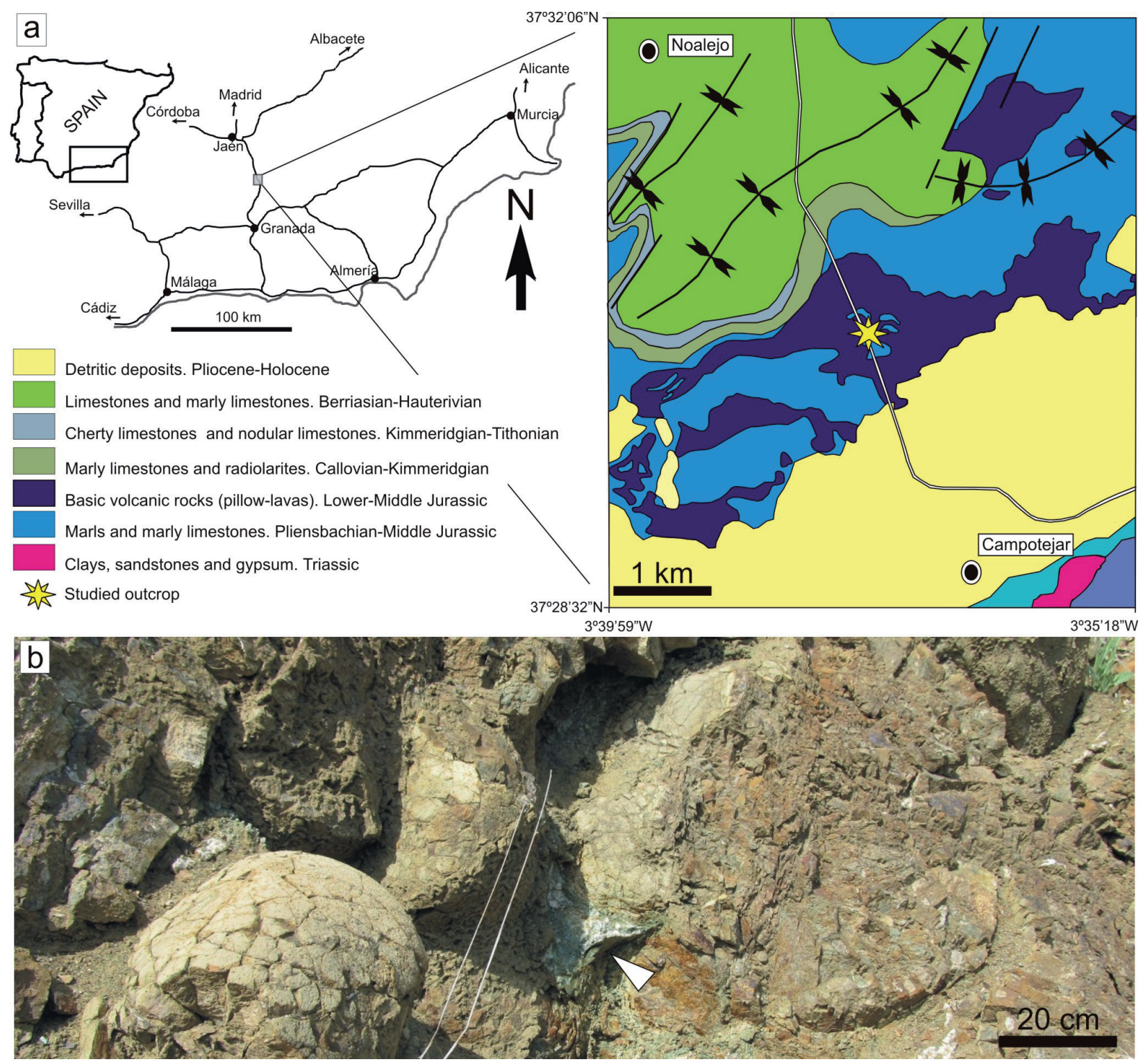

Fig. 1.- Location of the studied outcrop. a) Geographic location and geological setting of the Campotéjar pillow-lava outcrop. b) Field view of the pillow-lavas near km. 79 of the A-44 motorway (white arrow indicates vein among pillow-lava bodies).

cates were performed using wavelength-dispersive spectroscopy (WDX) on a Cameca SX100 at the CIC. The instrument was set at an accelerating voltage of $15 \mathrm{kV}$, with a beam current of $15 \mathrm{nA}$ and a electron beam diameter of $<5 \mu \mathrm{m}$. Data were reduced using the procedure of Pouchou and Pichoir (1985); the standards used were albite, sanidine, periclase, diopside, quartz, vanadinite, rutile, fluorite and synthetic oxides $\left(\mathrm{Al}_{2} \mathrm{O}_{3}, \mathrm{Fe}_{2} \mathrm{O}_{3}, \mathrm{NiO}\right.$ and $\left.\mathrm{MnTiO}_{3}\right)$. Finally, powdered portions of the crusts were prepared using $\mathrm{C}$-coated formvar $\mathrm{Cu}$ grids in a Philips CM20 (STEM) at the CIC equipped with a solidstate EDX detector, operating at $200 \mathrm{kV}$ and with $\mathrm{LaB}_{6}$ filament. Albite, biotite, spessartine, muscovite, olivine, titanite, $\mathrm{MnS}$ and $\mathrm{CaS}$ were used as standards to derive $\mathrm{K}$-factors for the transformation of intensity ratios to concentration ratios following the procedures of Cliff and Lorimer (1975). The structural formulae of glauconitic micas and smectites were calculated on the basis of 22 negative charges $\mathrm{O}_{10}(\mathrm{OH})_{2}$.
Whole-rock analyses of the green crusts (2 samples) were carried out at the CIC (Universidad de Granada) for major element oxides using X-ray fluorescence (XRF) with a Phillips PW 1040/10 spectrometer, whereas trace element contents were determined using an inductively coupled plasma-mass spectrometer (ICP-MS) Perkin Elmer Sciex-Elan 5000.

\section{Results}

The studied materials, occurring in the inter-pillow spaces, are predominantly green and white crystal growths. The morphology of the infilling is conditioned by the shape, irregular but sometimes stratiform, of these voids. The largest mineralisation found measured $55 \mathrm{~cm}$ in length.

The internal structure of these mineralisations is graded from the walls of the pillow-lava body outwards (Figs. 2 and 3). Usually, the walls are covered by planar laminated green 

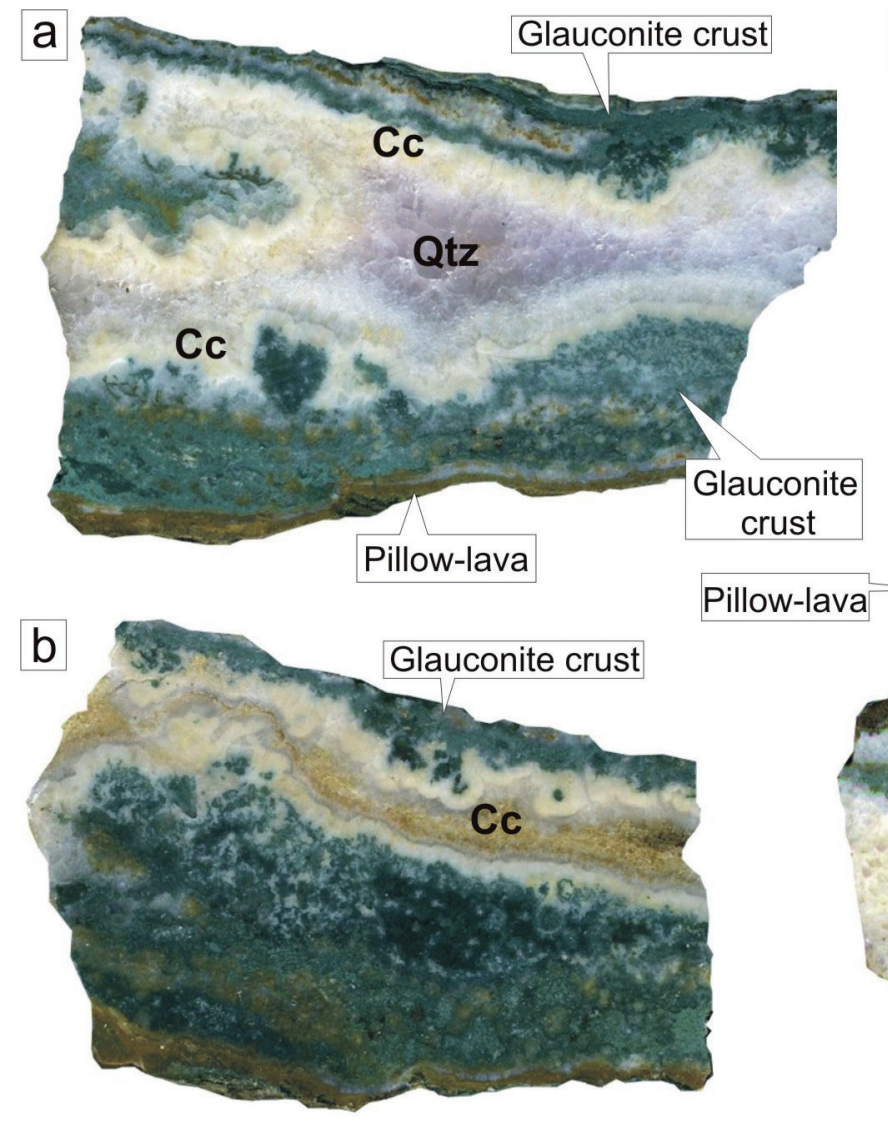

crusts (locally, very dark green). Inner parts of the mineralisations are composed by white crystals, predominantly calcite and secondarily quartz. Quartz usually occupies the most internal parts of the infilling. In some cases, when the infilling of the voids was not complete, they are preserved as geodes.

Two types of crusts can be differentiated according to mineralogy, colour and morphology: green laminated crusts, and black crusts and lentils.

\subsection{Green laminated crusts}

\section{Morphology and microstructure}

The green laminated crusts are usually developed from the walls of the pillow-lava showing a planar morphology with a thickness of 2-36 mm (mean value of $12 \mathrm{~mm}$ ) (Fig. 2). In some veins, bands of calcite crystals grow directly over pillow-lava walls or thin black films, and they are covered by the green laminated crusts (Fig. 2c). Commonly, the calcite and quartz mass occupying the most internal parts of the veins are crossed by green laminated columns stemming from the green laminated crusts commonly located directly on the walls of the pillow-lava (Fig. 3). The columns are $<$ $130 \mathrm{~mm}$ length and $<26 \mathrm{~mm}$ in diameter, and parallel to each other. Other irregular growths of green minerals occurring inside the calcite growth, sometimes resembling oncoid-like morphologies, are really transversal sections of columns (Fig. 3a, d).
Fig. 2.- Mineralogical zonation in the inter-pillow spaces with stratiform arrangement ( $a$ and $b$ ) and vertical veins (c). Note in (a) and (b) that green minerals are growing from pillow-lava walls followed by calcite $(\mathrm{Cc})$ and finally quartz (Qtz). In $\mathrm{c}$, green crust grows on the calcite band (red arrow), and not directly over pillow-lava.
Detailed analyses under magnifying glass and petrographic microscope allowed us to characterise the laminated texture of planar crusts and columns. In both cases, laminae are irregular and not densely packed, embedded in a quartz or calcitic matrix (Figs. 4 and 5). Laminae are 20-60 $\mu \mathrm{m}$ thick and made up of cylindrical filaments with a darker core (dark green or black) and a blue-green thin coat (Fig. 5). Some green filaments grow perpendicular to the lamination, measuring 100-450 $\mu \mathrm{m}$ in length (Fig. 4). Dichotomous branching is commonly observed in the perpendicular filaments (Fig. $4 \mathrm{~d}-\mathrm{f}$ ). The filaments are locally composed of an arrangement of microspheres (Fig. 4f).

Study of these filaments through SEM-BSE imaging of the thin sections reveals two parts: an inner part corresponding to the darker green core (on magnifying glasses) without textural traits, and an outer part consisting of a ring of needle-like crystals disposed as a coating around the inner part, with druse arrangement corresponding to the blue-green external coat (Fig. 6). The inner part is $22-45 \mu \mathrm{m}$ in diameter and the outer coating is $8-12 \mu \mathrm{m}$ thick. The calcite crystals near these filaments are adapted to the surface of the needlelike outer coating. In addition, SEM-BSE images show the generalised presence of voids at the centre of the filaments (Fig. 6b, black arrow). The width of the voids ranges from 3.5 to $8.5 \mu \mathrm{m}$. The wider the void, the less the material composing the darker green core in the inner part of the filaments. A very detailed examination of the inner and outer parts of the filaments under SEM-BSE images allowed us to 


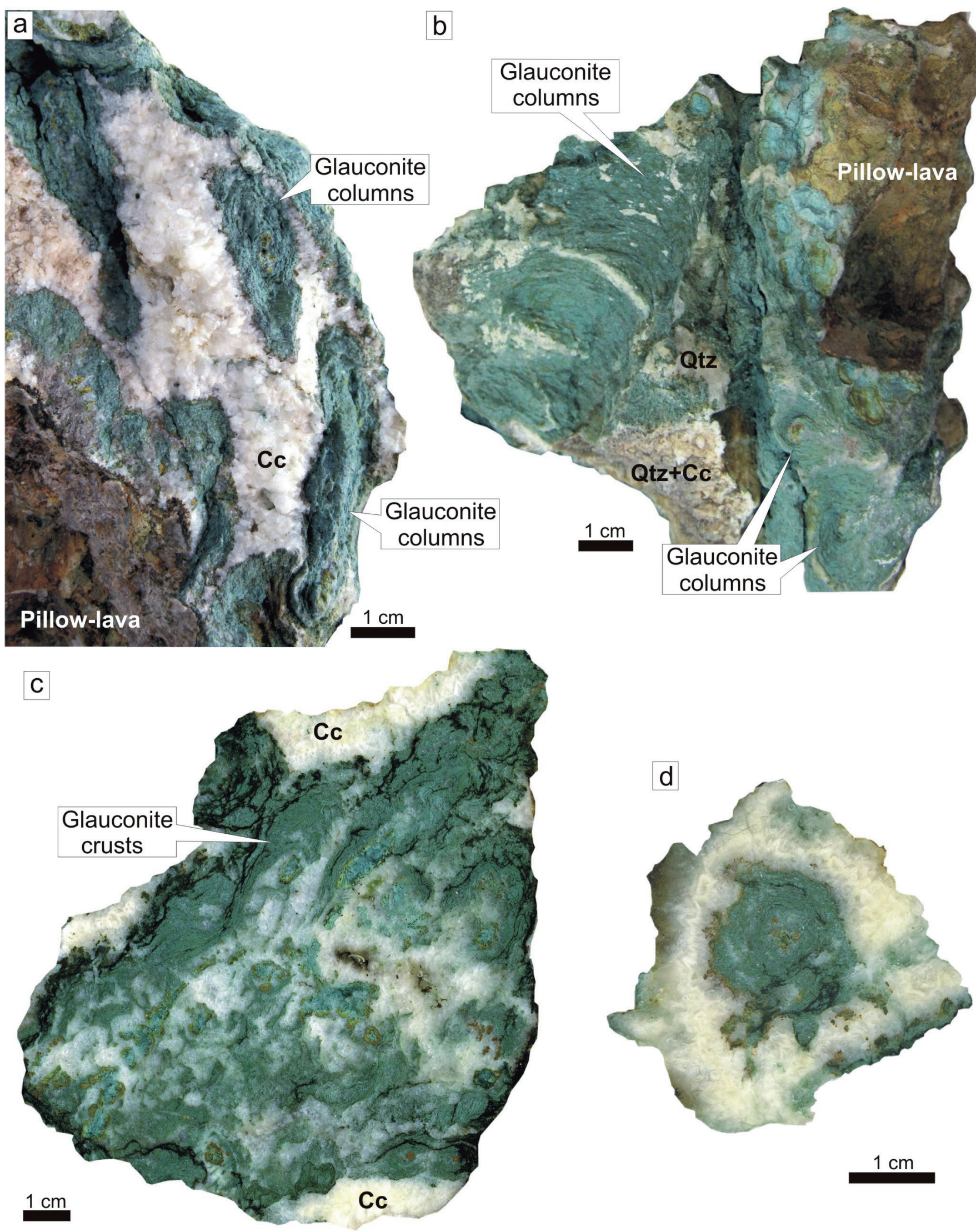

Fig. 3.- Examples of green crusts (composed by glauconitic micas, see below). a) Hand sample showing green laminated columns and oncoidlike morphologies surrounded by calcite $(\mathrm{Cc})$. b) Hand sample illustrating green laminated columns. c) Green laminated growths inside calcite crystal masses (polished slab). d) Transversal section of a green laminated column embedded in a calcitic background (polished slab). 

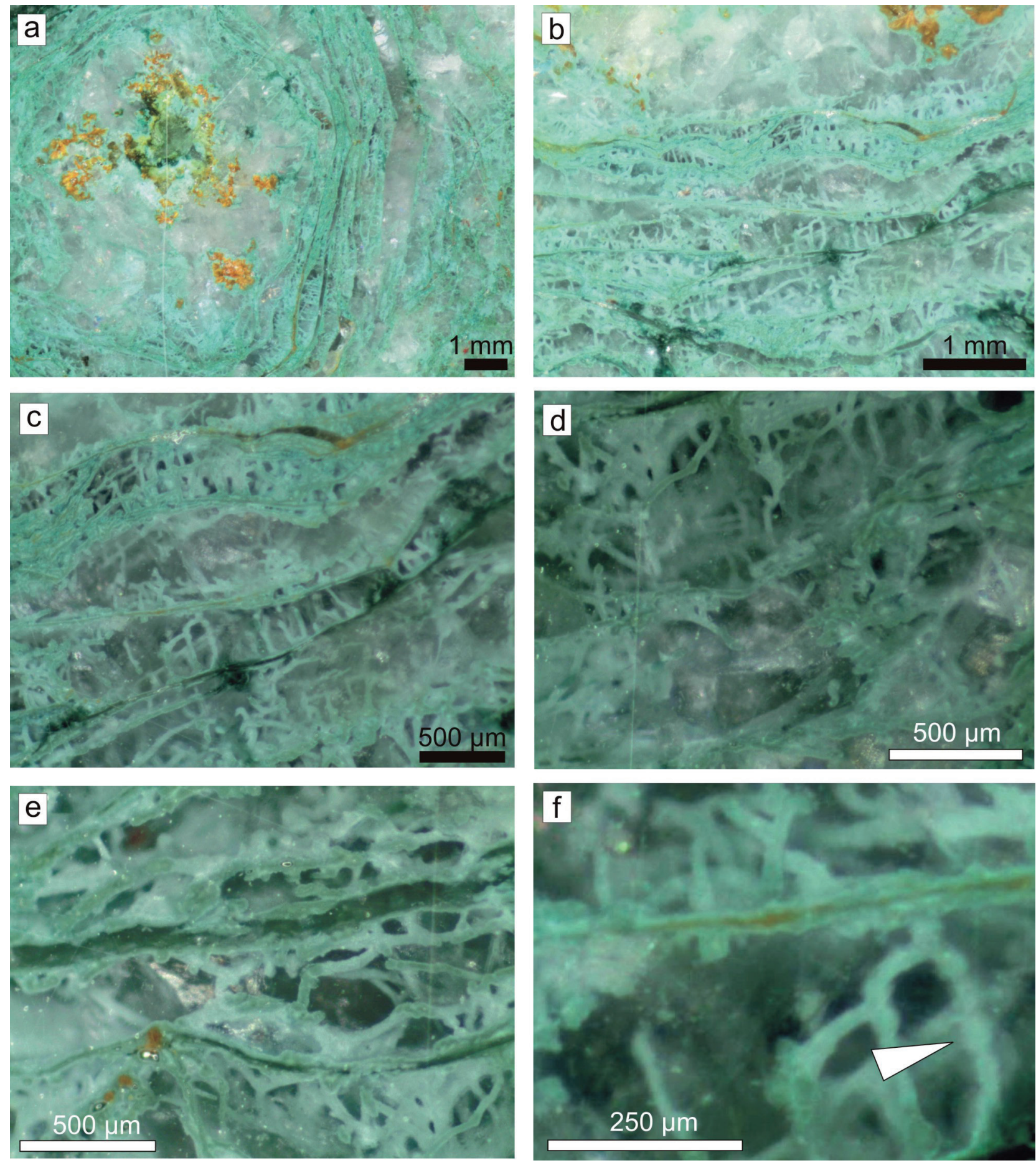

Fig. 4.- Filament structures from green laminated crusts (composed by glauconitic micas, see below) observed on thin sections and polished slabs under magnifying glass. a) Transversal section of a green laminated column surrounded by calcite. b), c) and d) Details of lamination with planar filamentous green laminae and perpendicular branching filaments. e) and f) Filaments composed by an arrangement of microspheres (see white arrow).

identify very small lath-like crystals $(<1 \mu \mathrm{m}$ length) making up the inner part, and comparatively larger lath-like crystals ( $>5 \mu \mathrm{m}$ length) composing the outer coating. The inner part is constituted by randomly arranged crystals, whereas in the outer part the crystals are oriented perpendicular to the filament. The transition between inner and outer parts is characterised by a progressive orientation of the crystals through palm-tree branches and progressively larger crystals (Fig. 7).

Secondary electron and TEM images show that the green material constituting the needle-like coating of the filaments actually consists of idiomorphic lath-like crystals $<10.5 \mu \mathrm{m}$ long and $<0.8 \mu \mathrm{m}$ wide (Fig. 8). Detailed examination of these lath-like crystals evidences that some samples present 

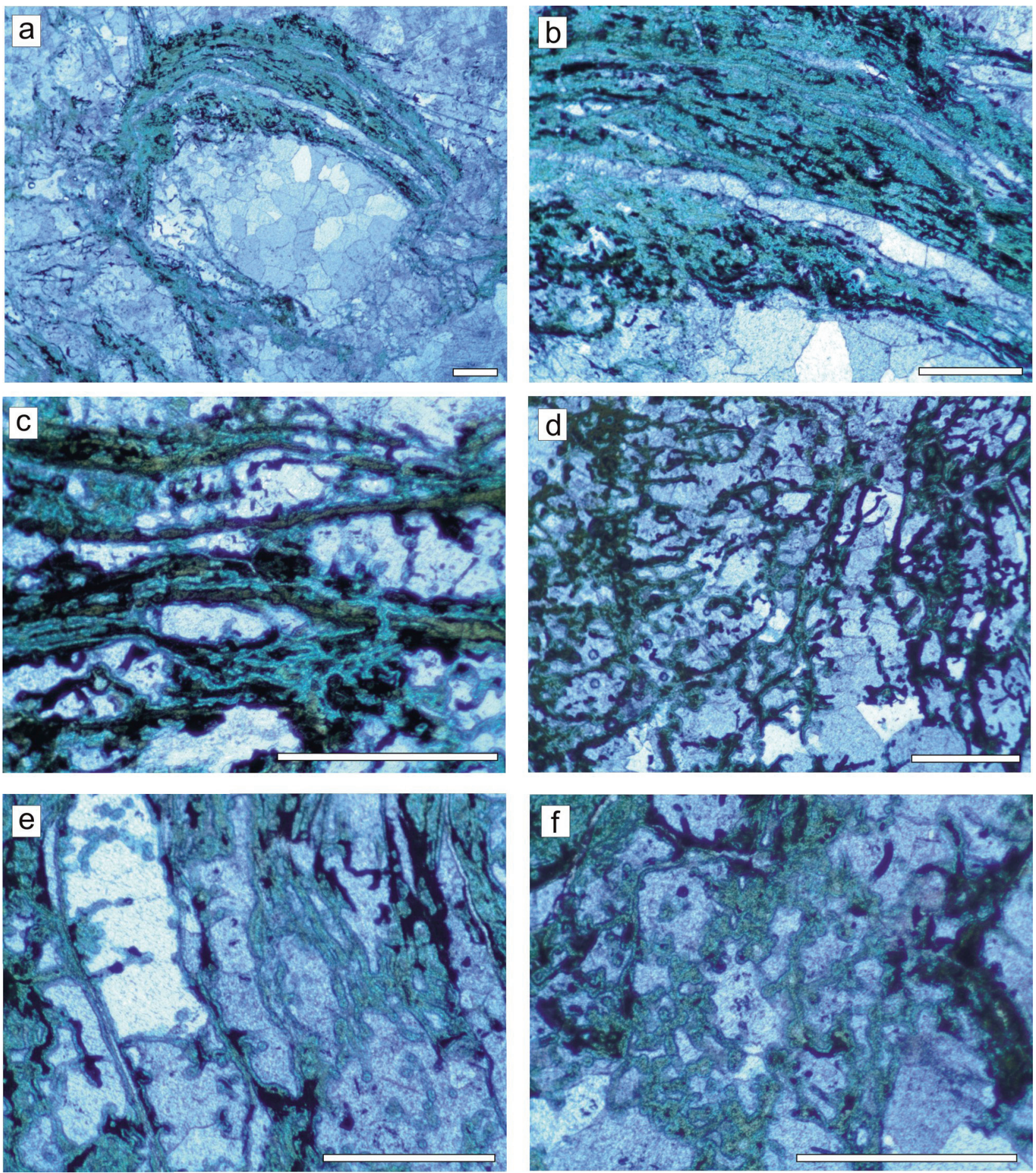

Fig. 5.- Images of green (glauconitic) laminated crusts under petrographic microscopy. a) General view of a green lamination surrounded by calcite with a mosaic texture. b) Dense accumulation of glauconitic laminae (light green) with smectites (dark green) and calcite crystals composing interlayers. c) Different green colours reflecting transition from different compositions in the glauconitic micas. d) Irregular growth of filaments with a calcitic background. e) and f) Filamentous appearance of green crusts and dark masses of smectites. Scale bar $=1 \mathrm{~mm}$.

irregular margins and small filamentous to coccoid-shaped forms with $<0.5 \mu \mathrm{m}$ length and $0.1 \mu \mathrm{m}$ width (Fig. 9a, b). The morphologies of the crystals are similar to the clay flakes described by Geptner et al. (2008) in glauconites from Paleogene volcano-terrigenous rocks from Kamchatka.

A characteristic irregular film covers the green crystals in some parts of the analysed samples (Fig. 9c, d), locally show- ing filament-like structures (locally branched) around $15 \mu \mathrm{m}$ in length and $<1 \mu \mathrm{m}$ in diameter (Fig. 9e, f).

\section{Mineralogy and geochemistry}

The XRD patterns of oriented aggregates corresponding to the green material show glauconitic mica, calcite, and a small 

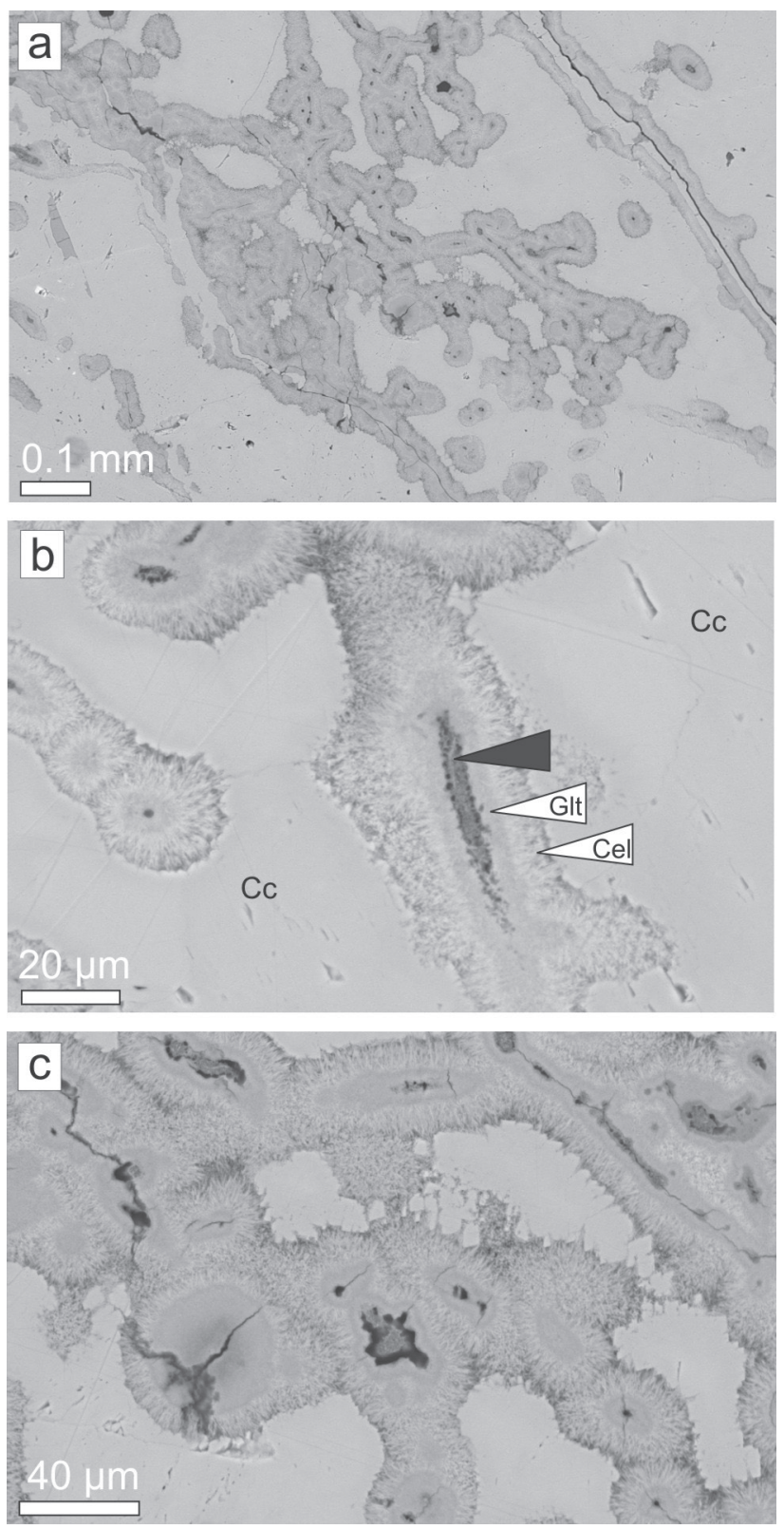

Fig. 6.- BSE images of the filaments. a) General view of filaments with longitudinal and transversal sections. b) Detailed view of green filaments with differentiation of three parts, the inner one being a void (black arrow), the intermediate one homogeneous glauconite (arrow Glt) and the outer one composed by thin needle-like crystals of celadonite (arrow Cel). The composition was established by XRD and chemical microanalyses. c) Filaments surrounded by calcite $(\mathrm{Cc})$ with a good view of voids occupying the centre of the filaments both from longitudinal and transversal sections.

amount of smectite with a basal spacing of $14.92 \AA$, which expands to $16.63 \AA$ after EG solvation (Fig. 10). The 001 reflection of the dioctahedral mica is a narrow peak with a sharp appearance and high intensity, which does not change its position, shape, and intensity after EG solvation. Nevertheless, the 003 peak is slightly asymmetric, with a small shoulder towards lower $2 \theta$ angles and close to $35^{\circ} 2 \theta$ showing two peaks, which is typical of celadonite (Odin and Mat-
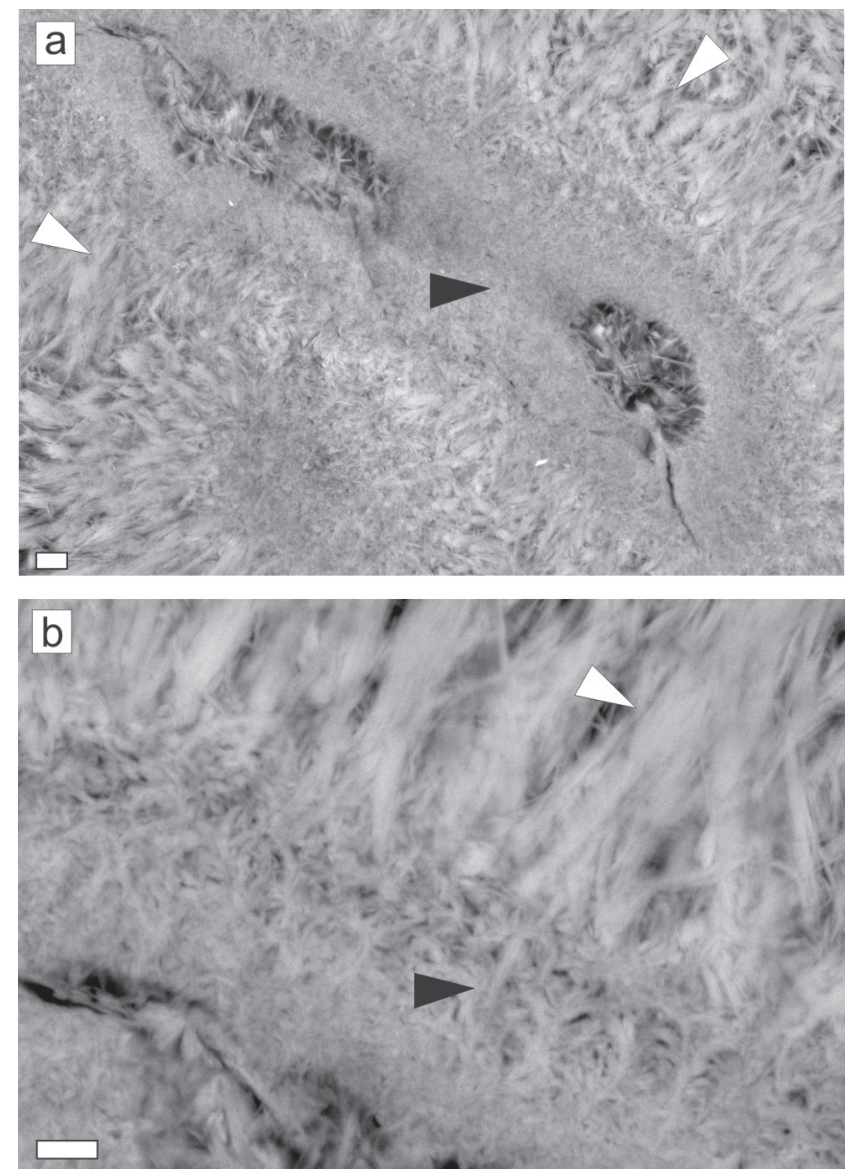

Fig. 7.- Detailed examination of the inner and outer parts of the filaments under SEM-BSE images. a) Small lath-like crystals composing the inner part (glauconite, black arrow) and comparatively larger lathlike crystals composing the outer coating (white arrow). b) Transition between inner (glauconite) and outer (celadonite) part characterised by a progressive orientation of the glauconite crystals organised like palm-tree branches with progressively larger crystals (black arrow). Scale bar $=1 \mu \mathrm{m}$.

ter, 1981). The sharp and symmetric peaks at 001 and 020 , and the presence of the $\overline{1} 12$ and 112 reflections, indicate a predominantly ordered structure.

The whole-rock analyses of the green crusts are characterised by a high loss on ignition (LOI) from $18.9 \%$ to $23.8 \%$. The major elements (in oxides) range from $27.79-34.38 \%$ for $\mathrm{SiO}_{2}, 20.23-26.69 \%$ for $\mathrm{CaO}, 8.66-10.38 \%$ for $\mathrm{Fe}_{2} \mathrm{O}_{3}$, $4.61-5.55 \%$ for $\mathrm{Al}_{2} \mathrm{O}_{3}, 4.39-5.44 \%$ for $\mathrm{K}_{2} \mathrm{O}$, and $3.27-3.97 \%$ for $\mathrm{MgO}$. The high values of $\mathrm{CaO}$ compared with literature data (Bornhold and Giresse, 1985) are related to the presence of calcite in the whole-rock sample of the green deposits. Regarding the trace elements, the most abundant are $\mathrm{Rb}$ (188 ppm), V (100 ppm), Cu (107 ppm), Li (70 ppm), and Ni (61 ppm), which are values close to the average composition of the upper continental crust (Taylor and McLennan, 1985) except for the $\mathrm{Cu}$ with a content twice the value of the Post Archean Average Shale (PAAS). The $\sum$ REE ranges between 15 and $19 \mathrm{ppm}$, which corresponds to REE-poor group of glauconites of Jarrar et al. (2000). 
Micro-chemical analyses of the studied growths made it possible to characterise the composition of glauconitic micas (glauconite and celadonite). The chemical compositions of dioctahedral micas are presented in Table 1. Si content is always $>3.70$ atoms per formula unit (a.f.u.) and the amount of $\mathrm{K}$ is $\geq 0.60$ a.f.u. with a sum of interlayer cations ( $\Sigma$ inter.) varying in the range of $0.66-0.99$ a.f.u. due to the presence of small quantities of $\mathrm{Ca}$. The octahedral sheet is characterised by $\mathrm{Fe}$ contents of $0.54-1.08$ a.f.u and $\mathrm{Al}$ and $\mathrm{Mg}$ contents in very similar quantities $(0.40-0.80$ a.f.u.). When these results are correlated with the BSE images of the filaments composing the laminated green crusts, clear differences can be seen among the chemical composition of lath-like crystals composing the outer coating of the filaments and the inner part (apparently homogeneous) also made up of lath-like crystals, yet smaller (Figs. 6, 7 and 11). The outer lath-like crystals show lower $\mathrm{Fe}$ contents and higher $\mathrm{Al}$ and $\mathrm{Mg}$ contents tan the inner crystals (Table 1, Fig. 11). In addition, there are clear differences in the $\mathrm{K}$ content of these two types of glauconitic micas. In the outer crystals, analyses reveal $\mathrm{K}$ contents ranging from $0.85-0.90$ a.f.u., which are greater than in the inner glauconites, where EDX analyses show $\mathrm{K}$ contents of between 0.60-0.69 a.f.u. However, the Ca content, while low in both cases, is higher in the inner crystals. The result is a higher content of interlaminar cations in the outer micas. Finally, the tetrahedral $\mathrm{Al}$ is $\geq 0.15$ a.f.u. in the inner micas, whereas it is always $\leq 0.16$ a.f.u. in the external crystals, as a consequence of a higher content of Si (Fig. 11b). These two sets of data point to two dioctahedral mica populations, glauconite and celadonite, as will be discussed later.

\subsection{Black crusts and lens-shaped nappes}

\section{Morphology and microstructure}

In addition to the green laminated crusts described above, irregular masses of dark green to black clay minerals have been recognised in the calcite infilling. They are lens-shaped discontinuous lentils or nappes $<20 \mathrm{~mm}$ long and $<3 \mathrm{~mm}$ thick (Fig. 12a). This material is also recorded in many samples as a thin black film or crust between the pillow-lava wall and the glauconitic micas of the green crust. In some cases calcitic growths may have formed earlier than the green laminated crust (Fig. 2c and 5a).

Under the petrographic microscope they appear to contain lath-like crystals $<450 \mu \mathrm{m}$ in length, randomly oriented (Fig. $12 \mathrm{~b}, \mathrm{c})$. However, BSE images show convolute veil-like morphologies with a certain chaotic appearance, typical of poorly crystallized grains of smectite (Fig. 13a, b). The transition between these aggregates of flakes, that coalesce or open, and the glauconitic micas composing the green laminated crust can be viewed in Fig. 13c-e. At TEM scale, the aspect of these flakes is subidiomorphic, with curled edges and fractures, sized $<1 \mu \mathrm{m}$ (Fig. 13f).
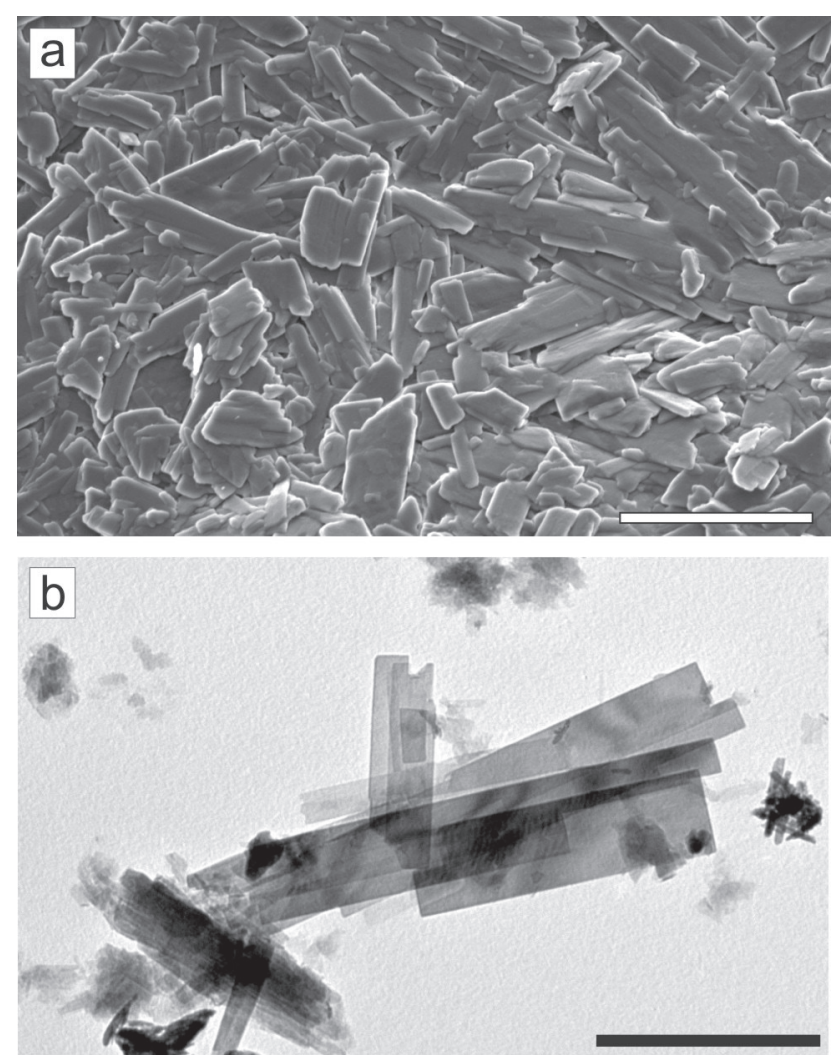

Fig. 8.- Electron microscopy images of lath-crystals of glauconitic micas in SEM (a) and TEM (b). Scale bar $=1 \mu \mathrm{m}$.

\section{Mineralogy and geochemistry}

The less-abundant dark green (almost black) material is smectite-rich as was corroborated by the XRD patterns of oriented aggregates. This smectite is characterised by a basal spacing of $14.6 \AA$, which expands to $16.56 \AA$ after EG treatment. Not only can the 001 reflection be detected, but also the 002, 003 and 005 reflections (Fig.14).

Micro-chemical analyses of the studied growths indicate a saponitic composition normalized to 22 charges (Table 2). The $\mathrm{Mg}$ content (up to 2.45 a.f.u.) is always greater than the $\mathrm{Fe}$ (up to 0.84 a.f.u.). The main cation in the interlayer is $\mathrm{Ca}$, ranging from 0.05 to 0.15 a.f.u.; $\mathrm{Na}$ is absent and $\mathrm{K}$ is always $<0.06$ a.f.u.. The substitution of $\mathrm{Si}$ for $\mathrm{Al}$ in the tetrahedral position is scarce $(<0.4$ a.f.u.).

\section{Interpretation}

The genesis of glauconitic minerals in sedimentary environments, widely studied in the literature, is commonly related to sea-bottom confined microenvironments under low sedimentation rate at water-depths ranging $60-350 \mathrm{~m}$ by crystallisation of glauconitic smectite (e.g., Odin and Matter, 1981; Odin and Fullagar, 1988; Amorosi, 1995). Maturation from nascent glauconite (glauconitic smectite) to highly evolved glauconite is related to a decrease in $\mathrm{Al}, \mathrm{Si}, \mathrm{Mg}, \mathrm{Ca}$ and $\mathrm{Na}$ and an increase in $\mathrm{K}$ and $\mathrm{Fe}$, producing a decreasing- 

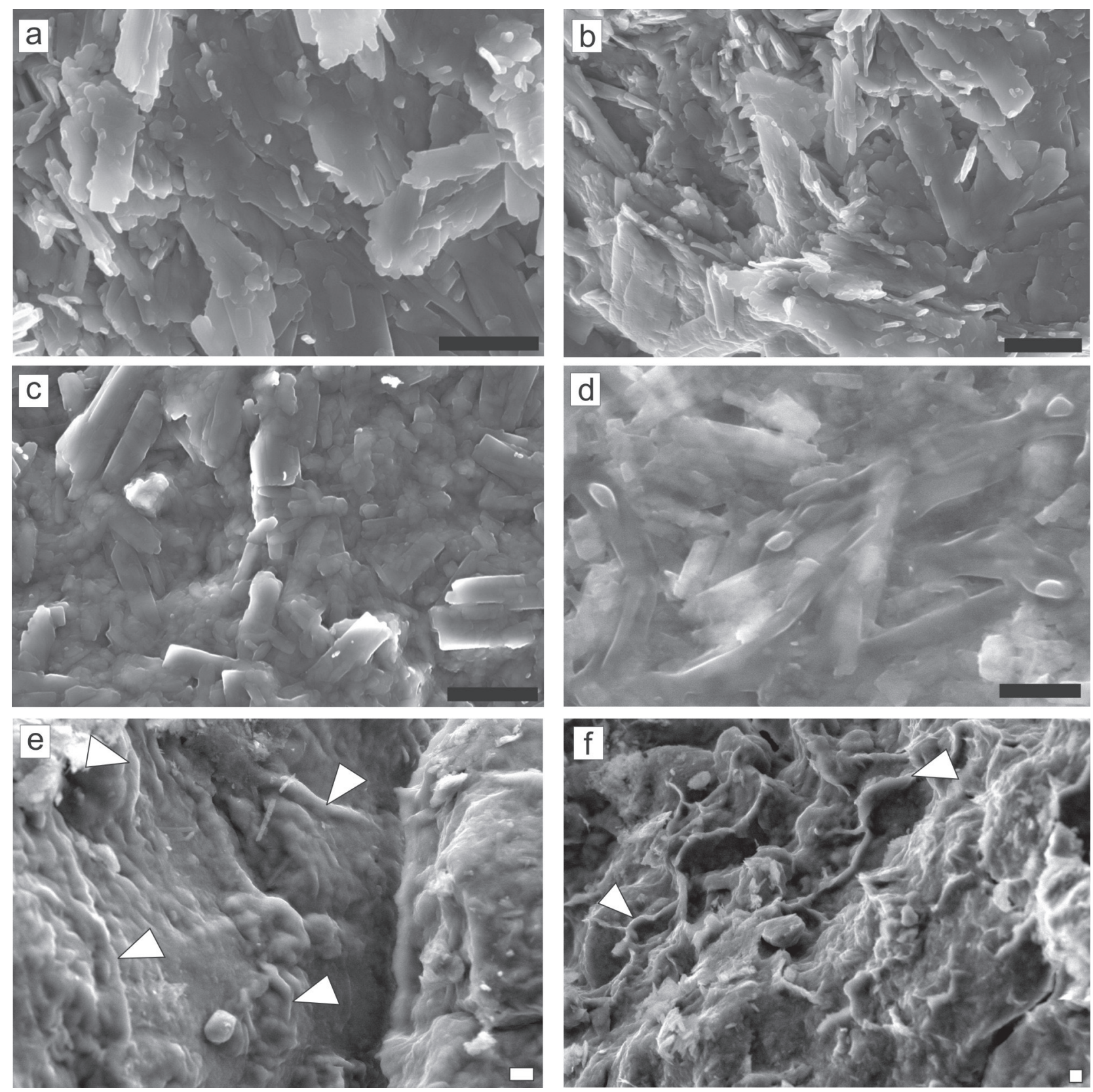

Fig. 9.- Secondary electron images of green laminated crusts. a) and b) Lath-like crystals showing irregular margins (clay flakes) and small filamentous to coccoid-shaped forms. c) Lath-like crystals immersed in a lumpy matrix with low crystallinity. d) Lath-like crystals covered by a veil-like film resembling microbial biofilm. e) and f) Filamentous structures (white arrows) over filmy veil-like surface. Scale bar $=1 \mu \mathrm{m}$.

ly expandable smectitic component (e.g., Odin and Matter, 1981; Amorosi, 1995; Eder et al., 2007; Sánchez-Navas et al., 2008). In such contexts, glauconite is an authigenic mineral developed as pelletal facies (mud coprolites, foraminiferal tests and mineral debris), and less frequently as films growing in holes, cracks and borings on hardgrounds and omission surfaces that may be associated with phosphates (e.g., Odin and Letolle, 1981; Odin and Matter, 1981; Fischer, 1990; Jiménez-Millán et al., 1998; Wigley and Compton, 2007). According to the chemical ranges for stages of glaucony evolution reported by Odin and Fullagar (1988), the $\mathrm{K}_{2} \mathrm{O}$ content of the glauconitic micas of this work indicates high maturity (Table 3, Fig. 15). In fact, the most mature glauconitic micas compositionally reach celadonite composition in view of the current nomenclature (Rieder et al., 1998; Tóth et al., 2010). Celadonite is the most evolved stage of glauconitisation according to Tóth et al. (2010), although in the geological literature the term glauconite is often applied to green grains at any stage of evolution (e.g. Odin and Fullagar, 1988). In this work, we report the textural transition between glauconite and celadonite (Fig. 7). The progressive orientation of the glauconite short lath-like crystals organized as palm-tree branches just in the transition, then through well-oriented large lath-like crystals of celadonite, is congruent with the most evolved stage interpreted as being celadonite with respect to earlier glauconite. 
Table 1.- Structural formulae for glauconitic micas of green material normalised to $\mathrm{O}_{10}(\mathrm{OH})_{2}$.

\begin{tabular}{|c|c|c|c|c|c|c|c|c|c|}
\hline & $\mathrm{Si}$ & ${ }^{\mathrm{IV}} \mathrm{Al}$ & ${ }^{\mathrm{VI}} \mathrm{Al}$ & $\mathrm{Fe}$ & $\mathrm{Mg}$ & Eoct & $\mathrm{K}$ & $\mathrm{Ca}$ & $\sum$ inter. \\
\hline \multicolumn{10}{|c|}{ inner micas (glauconite) } \\
\hline Crt 1032 & 3.79 & 0.21 & 0.50 & 0.98 & 0.49 & 1.97 & 0.66 & 0.13 & 0.79 \\
\hline Crt 1035 & 3.82 & 0.18 & 0.56 & 0.91 & 0.50 & 1.97 & 0.65 & 0.14 & 0.78 \\
\hline Crt 1038 & 3.74 & 0.26 & 0.44 & 1.05 & 0.51 & 2.00 & 0.66 & 0.11 & 0.77 \\
\hline Crt 1043 & 3.75 & 0.25 & 0.43 & 1.08 & 0.47 & 1.97 & 0.69 & 0.11 & 0.80 \\
\hline Crt 1045 & 3.76 & 0.24 & 0.44 & 1.05 & 0.49 & 1.98 & 0.68 & 0.11 & 0.79 \\
\hline Crt 1052 & 3.80 & 0.20 & 0.41 & 1.03 & 0.53 & 1.97 & 0.69 & 0.12 & 0.81 \\
\hline Car1 41 & 3.85 & 0.15 & 0.57 & 0.83 & 0.61 & 2.01 & 0.63 & 0.10 & 0.73 \\
\hline Car1 42 & 3.81 & 0.19 & 0.46 & 0.96 & 0.59 & 2.00 & 0.66 & 0.12 & 0.78 \\
\hline Car1 44 & 3.80 & 0.20 & 0.49 & 0.93 & 0.60 & 2.01 & 0.67 & 0.09 & 0.76 \\
\hline Car1 53 & 3.76 & 0.24 & 0.43 & 1.01 & 0.56 & 2.00 & 0.64 & 0.17 & 0.81 \\
\hline Car1 54 & 3.79 & 0.21 & 0.56 & 0.84 & 0.61 & 2.02 & 0.61 & 0.15 & 0.77 \\
\hline Car1 55 & 3.77 & 0.23 & 0.40 & 1.05 & 0.55 & 2.00 & 0.67 & 0.09 & 0.77 \\
\hline Car1 61 & 3.80 & 0.20 & 0.48 & 1.02 & 0.52 & 2.02 & 0.60 & 0.06 & 0.66 \\
\hline Car1 62 & 3.74 & 0.26 & 0.48 & 0.97 & 0.56 & 2.01 & 0.65 & 0.13 & 0.78 \\
\hline Car1 74 & 3.81 & 0.19 & 0.44 & 1.02 & 0.53 & 1.99 & 0.64 & 0.11 & 0.74 \\
\hline \multicolumn{10}{|c|}{ outer micas (celadonite) } \\
\hline Crt 1031 & 3.88 & 0.12 & 0.69 & 0.61 & 0.67 & 1.98 & 0.87 & 0.00 & 0.87 \\
\hline Crt 1034 & 3.85 & 0.15 & 0.65 & 0.66 & 0.63 & 1.94 & 0.87 & 0.08 & 0.95 \\
\hline Crt 1037 & 3.89 & 0.11 & 0.71 & 0.59 & 0.65 & 1.96 & 0.90 & 0.00 & 0.90 \\
\hline Crt 1042 & 3.84 & 0.16 & 0.67 & 0.66 & 0.62 & 1.95 & 0.89 & 0.05 & 0.94 \\
\hline Crt 1046 & 3.85 & 0.15 & 0.73 & 0.59 & 0.64 & 1.95 & 0.88 & 0.05 & 0.93 \\
\hline Crt 1051 & 3.84 & 0.16 & 0.65 & 0.64 & 0.66 & 1.95 & 0.89 & 0.08 & 0.97 \\
\hline Car1 46 & 3.91 & 0.09 & 0.74 & 0.57 & 0.79 & 2.10 & 0.86 & 0.00 & 0.86 \\
\hline Car1 47 & 3.94 & 0.06 & 0.75 & 0.55 & 0.77 & 2.08 & 0.88 & 0.00 & 0.88 \\
\hline Car1 48 & 3.88 & 0.12 & 0.65 & 0.76 & 0.71 & 2.12 & 0.85 & 0.00 & 0.85 \\
\hline Car1 72 & 3.97 & 0.03 & 0.71 & 0.54 & 0.79 & 2.03 & 0.86 & 0.13 & 0.99 \\
\hline
\end{tabular}

EDX analyses. Total $\mathrm{Fe}$ considered as $\mathrm{Fe}^{3}$

\begin{tabular}{|c|c|c|c|c|c|c|c|c|c|}
\hline & $\mathrm{Si}$ & ${ }^{\mathrm{IV}} \mathrm{Al}$ & ${ }^{\mathrm{VI}} \mathrm{Al}$ & $\mathrm{Fe}$ & $\mathrm{Mg}$ & Eoct & $\mathrm{K}$ & $\mathrm{Ca}$ & $\sum$ inter. \\
\hline CRNE A 1 & 3.65 & 0.35 & 0.14 & 0.72 & 2.18 & 3.05 & 0.00 & 0.11 & 0.11 \\
\hline CRNE A 2 & 3.64 & 0.36 & 0.15 & 0.84 & 2.00 & 2.99 & 0.06 & 0.15 & 0.22 \\
\hline CRNE A 4 & 3.65 & 0.35 & 0.15 & 0.76 & 2.14 & 3.05 & 0.01 & 0.08 & 0.09 \\
\hline CRNE A 6 & 3.64 & 0.36 & 0.16 & 0.77 & 2.13 & 3.06 & 0.01 & 0.07 & 0.07 \\
\hline CRNE A 10 & 3.70 & 0.30 & 0.17 & 0.65 & 2.20 & 3.02 & 0.01 & 0.08 & 0.09 \\
\hline CRNE A 13 & 3.65 & 0.30 & 0.13 & 0.73 & 2.20 & 3.05 & 0.01 & 0.11 & 0.12 \\
\hline CRNE A 15 & 3.67 & 0.33 & 0.13 & 0.54 & 2.34 & 3.02 & 0.01 & 0.15 & 0.15 \\
\hline CRNE A 16 & 3.67 & 0.33 & 0.14 & 0.55 & 2.34 & 3.03 & 0.01 & 0.13 & 0.14 \\
\hline CRNE A 17 & 3.70 & 0.30 & 0.15 & 0.54 & 2.32 & 3.01 & 0.01 & 0.11 & 0.13 \\
\hline CRNE A 21 & 3.68 & 0.32 & 0.18 & 0.59 & 2.21 & 2.98 & 0.01 & 0.16 & 0.18 \\
\hline CRNE A 22 & 3.68 & 0.33 & 0.11 & 0.52 & 2.44 & 3.06 & 0.01 & 0.07 & 0.08 \\
\hline CRNE A 24 & 3.70 & 0.30 & 0.11 & 0.51 & 2.45 & 3.07 & 0.01 & 0.05 & 0.06 \\
\hline CRNE A 26 & 3.71 & 0.29 & 0.13 & 0.50 & 2.39 & 3.04 & 0.00 & 0.07 & 0.08 \\
\hline CRNE A 27 & 3.73 & 0.27 & 0.14 & 0.49 & 2.41 & 3.04 & 0.01 & 0.05 & 0.06 \\
\hline CRNE A 29 & 3.66 & 0.34 & 0.14 & 0.56 & 2.33 & 3.03 & 0.00 & 0.13 & 0.14 \\
\hline CRNE A 31 & 3.67 & 0.33 & 0.17 & 0.57 & 2.26 & 3.00 & 0.01 & 0.14 & 0.15 \\
\hline CRNE B 7 & 3.72 & 0.28 & 0.12 & 0.56 & 2.36 & 3.04 & 0.01 & 0.07 & 0.08 \\
\hline CRNE B 8 & 3.81 & 0.19 & 0.20 & 0.52 & 2.21 & 2.94 & 0.02 & 0.08 & 0.10 \\
\hline CRNE B 10 & 3.76 & 0.24 & 0.14 & 0.49 & 2.37 & 3.01 & 0.00 & 0.07 & 0.07 \\
\hline
\end{tabular}

EMPA analyses. Total $\mathrm{Fe}$ considered as $\mathrm{Fe}^{2+}$
Table 2.- Structural formulae for smectites of the black crusts normalised to $\mathrm{O}_{10}(\mathrm{OH})_{2}$. the black to dark-green films between pillow-lava and green laminated crusts correspond almost exclusively to saponitic smectites (Fig. 16). Other mineral phases occupying more internal parts of the studied vein network are calcite and quartz.

The morphology and texture of the studied glauconitic micas is clearly different from the traditional classification of glaucony habits of Millot (1964) and other works (e.g., Odin and Fullagar, 1988), mainly focused on sedimentary environments. Given the type of deposits related to the infilling of among the pillow-lava bodies allowed us to identify glau-
conitic micas without a smectitic component. Nonetheless,

According to the AIPEA (Association Internationale pour l'Etude des Argiles) Nomenclature Committee, glauconite is defined as a Fe-rich dioctahedral mica with tetrahedral $\mathrm{Al}$ (or $\mathrm{Fe}^{3+}$ ) usually $>0.2$ a.f.u., and octahedral $\mathrm{R}^{3+}>1.2$ atoms (Bailey, 1980), which consist mainly of $\mathrm{Fe}^{3+}$, distinguishing from muscovite and phengitic micas. In this work, geochemical and mineralogical analyses of the green crusts recorded 
voids and veins among pillow-lavas, the environmental context for the genesis of the studied glauconite must be related to hydrothermal rather than sedimentary processes. However, these glauconites are exceptional in the literature because previous (scarce) descriptions of glauconite in hydrothermal environments refer to granular/pelletal glauconites and not to laminated crusts and columns (Buatier et al., 1989, 1993; D'Antonio and Kristensen, 2005; Ionescu et al., 2006; Geptner et al., 2008; Clauer et al., 2011). In addition, celadonite is a typical hydrothermal alteration product of marine basalts in the field veinlets (Andrews, 1980; Delmont, 1985; Staudigel et al., 1986; Odin et al., 1988; Tazaki and Fyfe, 1992; Renac et al., 2010; Tóth et al., 2010). It is likely that some studies reporting glauconite from hydrothermal environments are in fact describing celadonite.

\subsection{Glauconitic micas and hydrothermal alteration}

The composition of the veins filling inter-pillow spaces in the Median Subbetic is very important when interpreting the genetic conditions. Secondary clay minerals and their association with carbonates can reveal whether the alteration occurred under oxidizing or reducing conditions, as a direct consequence of the fluid/rock mass ratio (D'Antonio and Kristensen, 2005; Renac et al., 2010). If the main phase of hydrothermal alteration occurred under oxidizing conditions with a high sea-water/rock ratio, in an open-circulation regime, it would precipitate abundant glauconite and celadonite. Andrews (1980) observed that celadonite forms on fissures open to the top of the volcanic pile (with presence of nannofossils), which is significant in terms of the probable origin of the fluids from which celadonite forms. In addition, when fluids circulate quickly, the environment is sufficiently oxidized for celadonite crystal growth. According to D'Antonio and Kristensen (2005), a high LOI confirms a high sea-water/rock ratio; in the samples of the Median Subbetic, values from $18.9 \%$ to $23.8 \%$ were detected from XRF analyses.

The studied green crusts composed by clay minerals mainly glauconite and celadonite, and to a lesser extent by saponitic smectites - appear surrounded by white crystal masses of calcite and quartz, where the black crust and lensshaped nappes of saponite are recorded (Figs. 2, 3 and 12). Nevertheless, glauconite and celadonite are ferric 2:1 phyllosilicates, which implies that the two minerals formed in a semi-confined environment with cation-rich fluids (Odin et al., 1988). The environment cannot be extremely confined (reducing), because the iron in these micas is mainly ferric. In addition, as it is well-documented that the oxidation of iron can be readily mediated by neutrophilic microbes under very low oxygen conditions (e.g. Benz et al., 1998), we cannot exclude the activity of iron-oxidizing microbes. Studies on the hydrothermal alteration of basalts by sea-water at low temperature show an early oxidative phase (Odin et al., 1988; Alt, 1999; Clayton and Pearce, 2000; D'Antonio and Kristensen, 2005). The early alteration mainly proceeds as circulation and diffusion of oxygenated sea-water along veins and inter-pillow spaces coupled with diffusion into the rock
Fig. 10.- XRD patterns of air-dried (AD) and ethylene glycol (EG) solvated samples from light green crusts. Cc: calcite, Cel: celadonite, Glt: glauconite, Sm: smectite. Peaks corresponding to Glt and $\mathrm{Cel}$ coincide, except for the two peaks designated as $\mathrm{Cel}$, which are exclusive of celadonite.

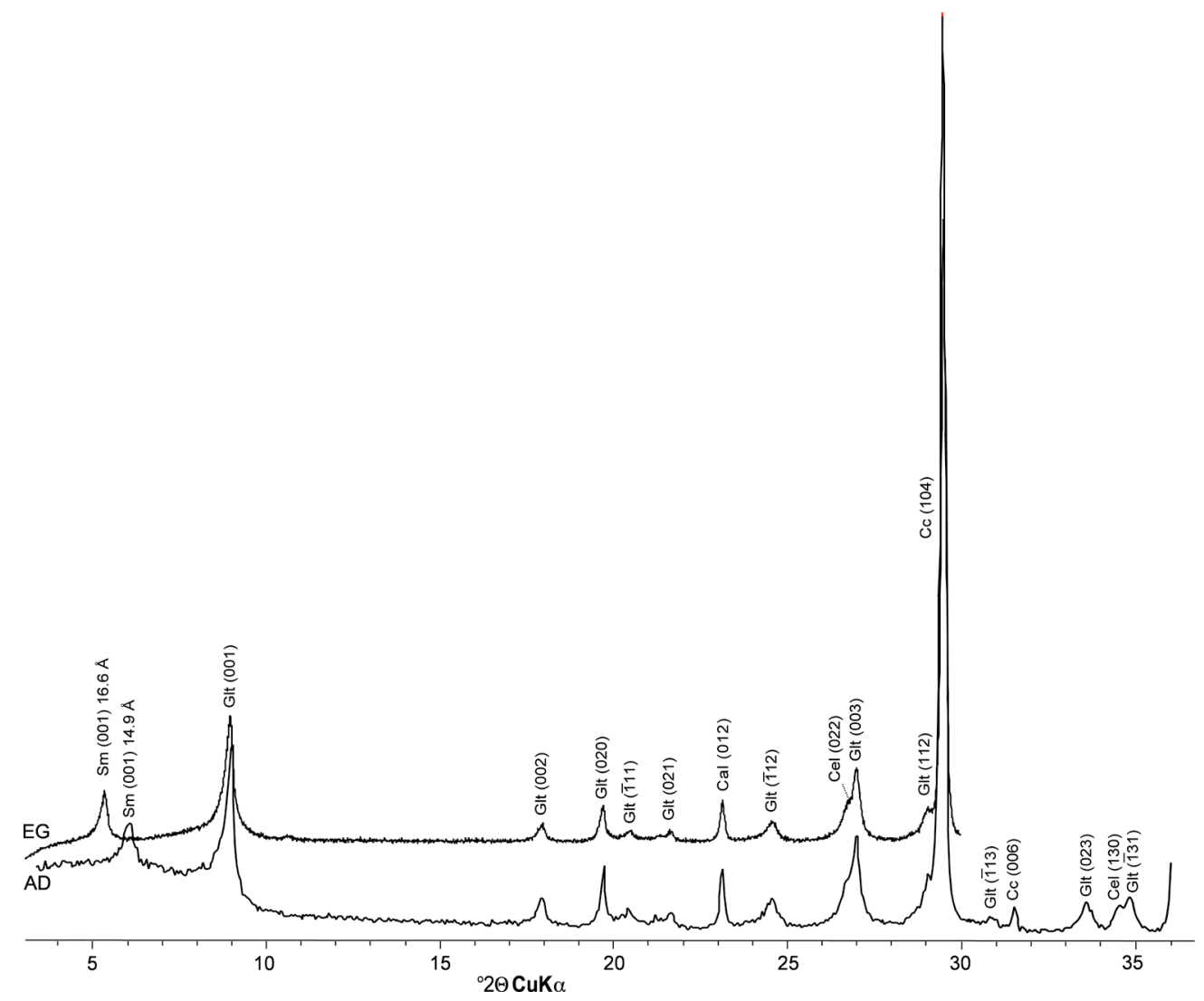


(Alt, 1999; Clayton and Pearce, 2000). Another example is shown by Clauer et al. (2011), with crystallisation of glauconite and nontronite generated from hydrothermal fluids mixed with seawater in hydrothermal mounds near the Galapagos Spreading Center. Fe was mobilised by a breakdown of volcanic glass or hydrothermal fluids (in that case $\mathrm{Fe}^{2+}$ ), while sea-water had to be an additional supplier of K (Clayton and Pearce, 2000; D'Antonio and Kristensen, 2005; Renac et al., 2010; Baker et al., 2012). The volcanic edifices of the Median Subbetic are composed of K-rich pillow-lavas (Vera et al., 1997) and they are potential sources of K. Thus, $\mathrm{Fe}$ and $\mathrm{K}$ had to be added to the oxidation zone and fixed in the precipitation of Fe-rich dioctahedral micas (glauconite and celadonite).

Regarding the temperature of these deposits, the absence of secondary minerals such as chlorite, epidote and albite constrains the temperature of the hydrothermal alteration under zeolite-facies conditions $\left(<100-150^{\circ} \mathrm{C}\right)$. According to Clayton and Pearce (2000) and D'Antonio and Kristensen (2005), the glauconite precipitation occurred at temperatures ranging $30-60^{\circ} \mathrm{C}$. Recently, Clauer et al. (2011) recorded a crystallisation temperature of $32-63^{\circ} \mathrm{C}$ from $\delta^{18} \mathrm{O}$ values in the Galapagos Spreading Center. In turn, Stakes and O'Neil (1982) and Odin et al. (1988) interpret temperatures $<50^{\circ} \mathrm{C}$ to form celadonite from $\delta^{18} \mathrm{O}$ values, in agreement with the context of our studied samples. However, Odin et al. (1988) and Desprairies et al. (1989) affirm that celadonite occasionally forms at temperatures between 50 and $90^{\circ} \mathrm{C}$.

Andrews (1980), Desprairies et al. (1984) and Delmont (1985) emphasised the association of celadonite with a black ferriferous saponite from veins developed in marine volcanic rocks. According to our observations, a late phase of alteration is typified by the formation of saponite and must have taken place under confined conditions resulting from the deposition of marine sediments. When iron-bearing fluids circulate more slowly or are trapped, then the environment is dominated by the reducing property of the pillow-basalt. According to D'Antonio and Kristensen (2005), glauconite characterises hydrothermal alteration under oxidizing conditions, whereas saponite and calcite characterise alteration under reducing conditions. In this sense, Clayton and Pearce (2000) established a clay-mineral transition from interestratified glauconite-nontronite, interstratified smectite-glauconite and saponite/beidellite mixture depending on the distance from fluid conduits. Moreover, we must bear in mind the local record of thin films of saponite directly on pillow-lava surfaces, before the development of the thick green laminated crusts. At any rate, there are significant similarities between the products of low temperature hydrothermal alteration in the pillow-lavas of this study as compared with those from ocean-ridge basalts and oceanic crusts (Alt, 1999; Clayton and Pearce, 2000; D'Antonio and Kristensen, 2005), with the presence of early Fe-rich dioctahedral micas followed by a later formation of saponite and carbonates.

The saponite composition of the studied crusts is characterised by a predominance of $\mathrm{Ca}$ in the interlayer (Table 2). Part of the Ca composing the hydrothermal fluids and favouring the precipitation of calcite and Ca-saponite was supplied by the surrounding limestones that were simultaneously altered. That is, after the burial of volcanic rocks by marine sediments, with the limitation of the sea-water circulation, the hydrothermal process favoured the precipitation of saponite and calcite under higher temperatures than the glauconitic ones. The restricted cold sea-water circulation led to increasing temperature and reducing conditions. The proposals of estimated saponite formation temperatures from $\delta^{18} \mathrm{O}$ values reportedly range $130-170^{\circ} \mathrm{C}$ (Stakes and O'Neil, 1982) or $70^{\circ}-130^{\circ} \mathrm{C}$ (Desprairies et al., 1989); that is, always higher temperatures than for glauconite and celadonite.

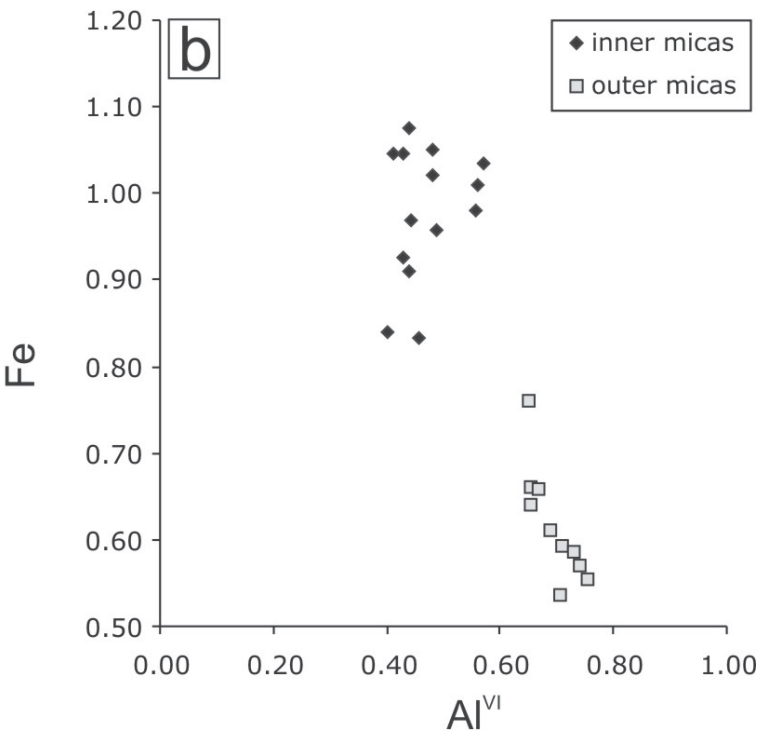

Fig. 11.- Diagrams of the chemical composition of glauconitic micas analysed in the green crusts. The black symbols represent the inner micas and the grey symbols the outer micas (see explanation in the text). 

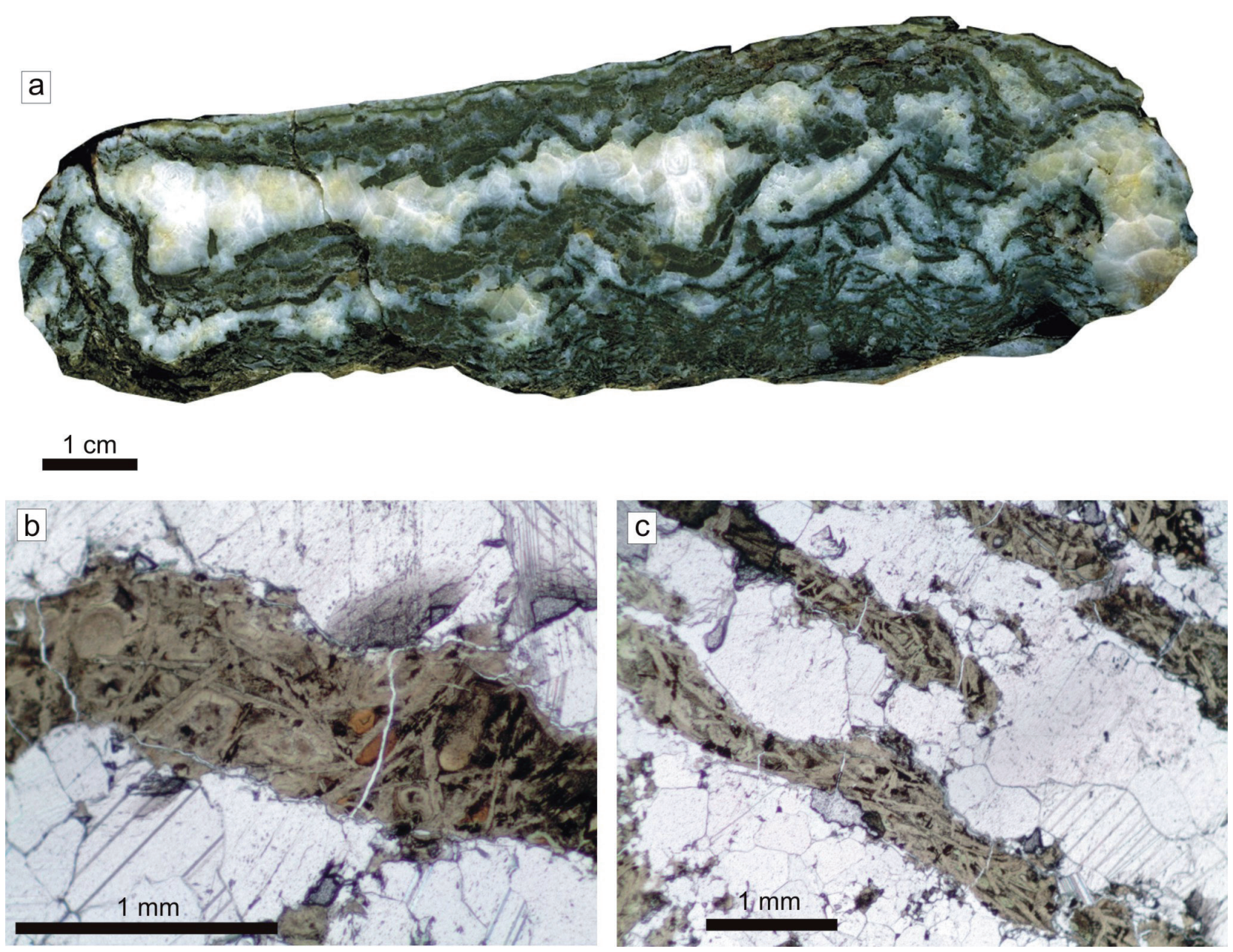

Fig. 12.- Images of irregular masses of dark green to black mineralizations in the calcite infilling. a) Polished slab oriented of a calcitic vein (top in the upper part). b) and c) View of lens-shaped mineralizations under petrographic microscope.

The thicker mineralisations of saponite form lens-shaped nappes inside calcitic veins (Fig. 12) with scarce glauconiteceladonite crystals, observed only under microscopy and BSE imaging (Figs. 13c-e). The transition from glauconitic micas to saponite is compositionally sharp, although texturally saponite presents the same lath-like appearance as glauconitic micas and progressively changes to a convoluted veil-like appearance away from the mineral boundary (Fig. 13c-e). This textural transition allows us to envisage saponite growing on and consuming previous glauconitic micas.

Low temperature hydrothermal alteration occurring in marine environment has been described in the Upper Jurassic basic volcanics of Transylvania with the presence of glauconite and Fe-saponite (Ionescu et al., 2006). D'Antonio and Kristensen (2005) analysed the secondary minerals generated by hydrothermal alteration affecting the basalts of oceanic crust in the West Philippine Sea Basin and recorded clay minerals, mostly glauconite, minor Al-saponite and Fe-beidellite, together with iddingsite, $\mathrm{Ca}-\mathrm{Na}$ zeolites and calcite. Abad et al. (2003), in the Median Subbetic (Betic Cordillera), recorded and analysed saponite at the contact of marl-limestone rhythmites with a laccolith of dolerites as a consequence of hydrothermal alteration facilitated by an intense fracturation and the circulation of lower-temperature fluids; in the slightly altered rocks Ca-zeolites were also found (Jiménez-Millán et al., 2007). Saponite has also been described in relation to alteration process of marls by basaltic dykes (Henry et al., 2007) and in mudstones and limestones locally metasomatised by the emplacement of a basic sill (Kemp et al., 2005).

Four phases are proposed for the infilling of the veins and inter-pillow spaces of the studied outcrop (Fig. 17):

Very early alteration of the pillow-lava surface, with the influence of reducing fluids and under moderate temperatures $\left(<200^{\circ} \mathrm{C}\right)$ during the last episode of volcanic activity recorded by the local black films of saponite and calcite;

Glauconitic micas (glauconite and celadonite) forming later at lower temperature $\left(<100^{\circ} \mathrm{C}\right)$ under oxic conditions due to the circulation and diffusion of oxygenated sea-water along veins and inter-pillow spaces (oxidation of $\mathrm{Fe}^{2+}$ would be promoted by environmental conditions or microbial activity);

A second stage of saponite formation with calcite taking place under more confined/reducing conditions and comparatively higher temperature resulting from the deposition of marine sediments, probably affecting previous glauconitic micas; 

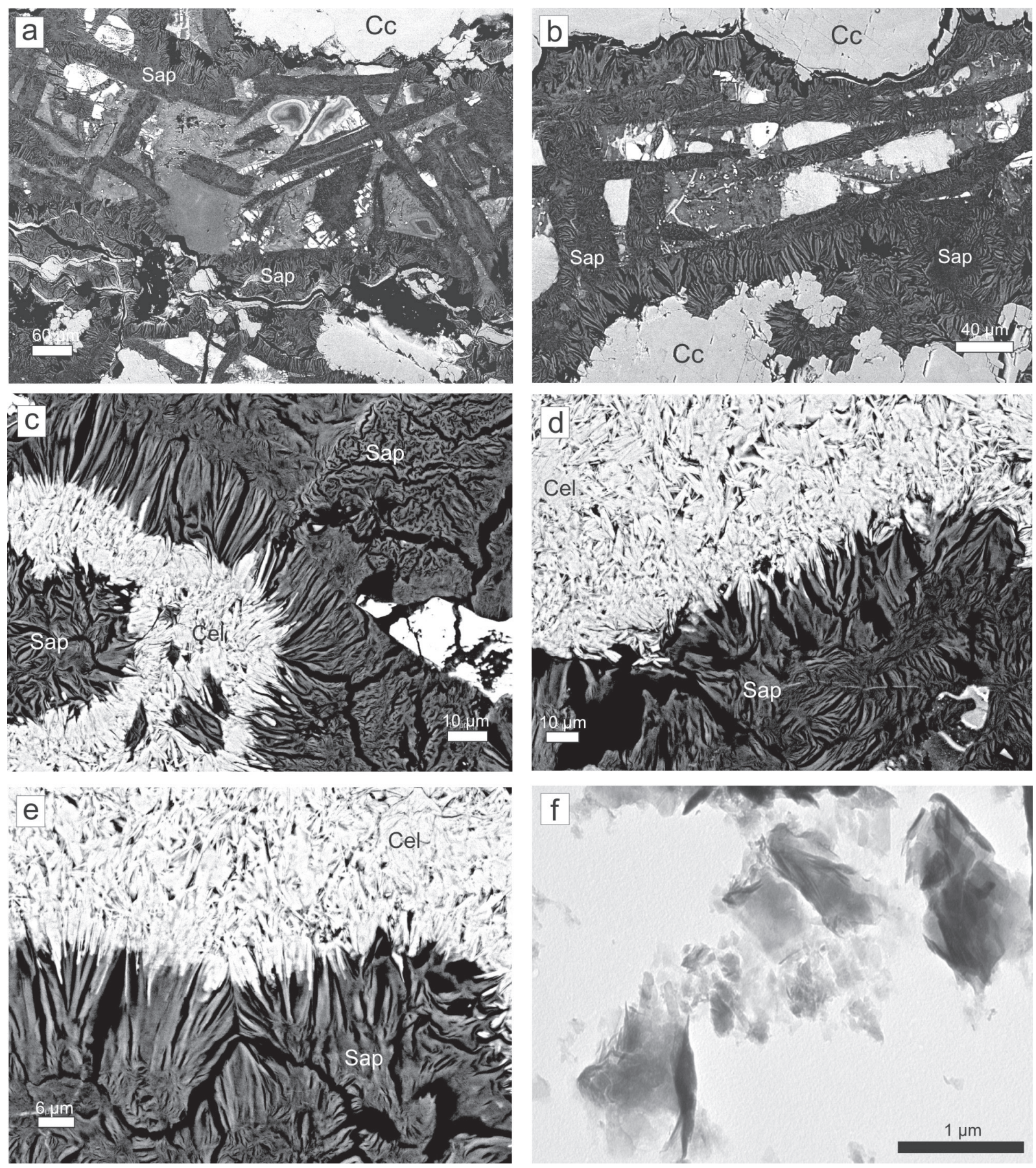

Fig. 13.- Electron microscopy images of black to dark-green mineralizations. a) and b) BSE images of the textural aspect of the elongated voids occupied by these mineralizations surrounded by calcite crystals. c) and d) BSE images of the textural relation between celadonitic crystals and aggregates of saponitic flakes. e) Detail of the transition between the two minerals. f) TEM bright field of veil-like particles of saponite with curled edges.

Calcite and quartz became the latest product to close the remaining space (or producing geodes) among the pillow-lava bodies.

\subsection{Presence of microbes during glauconite formation}

The record of filaments and coccoid-shaped forms at different scales indicates the potential implication of microbes in the growth of the green laminated crusts (see Figs. 4-7 and 9). The presence of voids occupying the centre of the filaments composing the green laminated crust points to this possibility (Fig. 6). Moreover, the film showing filament-like structures covering the glauconitic crystals in some samples analysed would correspond to biofilm (Figs. 9e, f).

Benthic microbial communities are ubiquitously found on pillow-lavas in recent ocean crust (e.g. Edwards et al., 2005; Santelli et al., 2008; Santelli, 2009). According to Bach and Edwards (2003) and Santelli et al. (2008), basalt alteration 


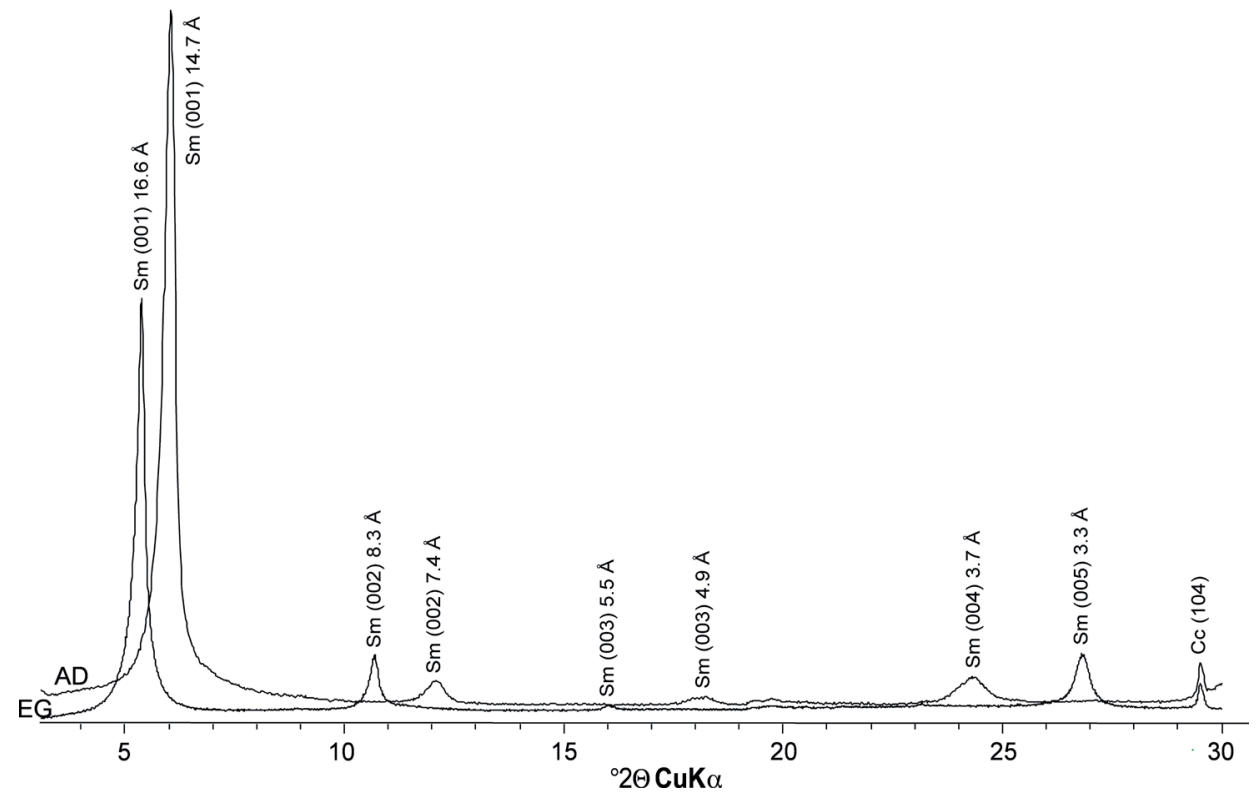

Fig. 14.- XRD patterns of air-dried (AD) and ethylene glycol (EG) solvated samples from dark green material. Cc: calcite, Sm: smectite.

Fig. 15.- $\mathrm{K}_{2} \mathrm{O}$ versus $\mathrm{Fe}_{2} \mathrm{O}_{3}$ plot for the glauconitic micas analysed from the green laminated crusts (EMPA analyses).

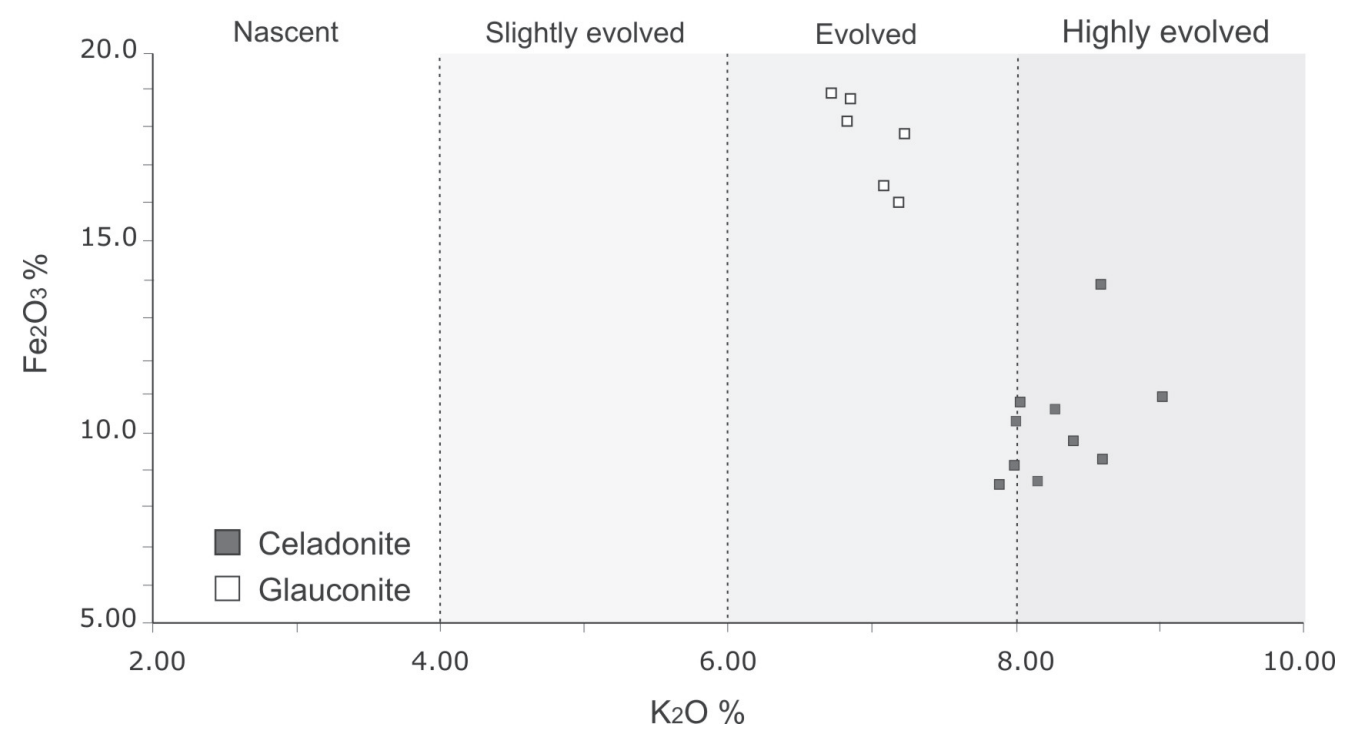

CRTE 1 CRTE 1 CRTE 1 CRTE 1 CRTE 1 CRTE 1 CRTE 1 CRTE 1 CRTE 1 CRTE 1 CRTE 1 CRTE 1 CRTE 1 CRTE 1 CRTE 1 CRTE 1

\begin{tabular}{ccccccccccccccccc} 
& 1 & 2 & 4 & 5 & 7 & 8 & 10 & 11 & 12 & 13 & 15 & 16 & 17 & 18 & 19 & 20 \\
\hline $\mathrm{SiO}_{2}$ & 51.93 & 52.46 & 46.16 & 48.02 & 49.09 & 51.08 & 48.13 & 50.69 & 47.56 & 47.40 & 51.34 & 44.61 & 48.05 & 47.92 & 47.63 & 47.72 \\
$\mathrm{Al}_{2} \mathrm{O}_{3}$ & 8.33 & 9.08 & 8.04 & 8.13 & 6.81 & 7.76 & 6.82 & 7.13 & 7.89 & 7.88 & 7.04 & 6.95 & 6.74 & 7.89 & 8.08 & 7.84 \\
$\mathrm{MgO}$ & 6.19 & 6.68 & 5.77 & 5.91 & 4.80 & 4.80 & 4.88 & 4.71 & 5.87 & 5.91 & 5.36 & 5.65 & 5.12 & 6.01 & 6.03 & 6.19 \\
$\mathrm{Fe}_{2} \mathrm{O}_{3}$ & 13.92 & 10.95 & 9.13 & 10.66 & 18.18 & 18.76 & 16.39 & 18.90 & 10.80 & 10.28 & 17.83 & 8.63 & 15.97 & 9.76 & 8.75 & 9.32 \\
$\mathrm{MnO}$ & 0.00 & 0.02 & 0.00 & 0.01 & 0.04 & 0.04 & 0.01 & 0.03 & 0.04 & 0.00 & 0.03 & 0.04 & 0.03 & 0.01 & 0.02 & 0.01 \\
$\mathrm{TiO}_{2}$ & 0.00 & 0.00 & 0.00 & 0.00 & 0.00 & 0.00 & 0.01 & 0.00 & 0.00 & 0.00 & 0.00 & 0.00 & 0.00 & 0.00 & 0.00 & 0.00 \\
$\mathrm{Cr}_{2} \mathrm{O}_{3}$ & 0.00 & 0.00 & 0.02 & 0.02 & 0.01 & 0.00 & 0.02 & 0.02 & 0.05 & 0.00 & 0.00 & 0.01 & 0.05 & 0.02 & 0.04 & 0.00 \\
$\mathrm{NiO}$ & 0.05 & 0.00 & 0.00 & 0.00 & 0.00 & 0.00 & 0.01 & 0.00 & 0.00 & 0.00 & 0.01 & 0.01 & 0.00 & 0.00 & 0.00 & 0.00 \\
$\mathrm{~K}_{2} \mathrm{O}$ & 8.57 & 9.01 & 7.96 & 8.25 & 6.82 & 6.83 & 7.08 & 6.70 & 8.01 & 7.99 & 7.21 & 7.87 & 7.17 & 8.38 & 8.14 & 8.58 \\
$\mathrm{CaO}$ & 0.25 & 0.23 & 0.18 & 0.25 & 0.68 & 0.66 & 0.65 & 0.64 & 1.00 & 0.43 & 0.61 & 0.20 & 0.52 & 0.26 & 0.26 & 0.55 \\
$\mathrm{Na} 2 \mathrm{O}$ & 0.02 & 0.02 & 0.00 & 0.01 & 0.01 & 0.02 & 0.00 & 0.01 & 0.01 & 0.00 & 0.02 & 0.00 & 0.05 & 0.02 & 0.00 & 0.00 \\
$\mathrm{~F}$ & 0.16 & 0.18 & 0.16 & 0.14 & 0.20 & 0.19 & 0.20 & 0.16 & 0.14 & 0.16 & 0.15 & 0.16 & 0.22 & 0.17 & 0.15 & 0.12 \\
$\mathrm{Cl}$ & 0.10 & 0.10 & 0.17 & 0.18 & 0.12 & 0.08 & 0.09 & 0.12 & 0.18 & 0.15 & 0.10 & 0.21 & 0.20 & 0.19 & 0.17 & 0.22 \\
$\mathrm{Total}$ & 89.01 & 88.45 & 77.26 & 81.26 & 86.45 & 89.96 & 83.99 & 88.83 & 81.23 & 79.89 & 89.45 & 73.97 & 83.70 & 80.26 & 78.95 & 80.23
\end{tabular}

Table 3.- Chemical composition of glauconitic micas (wt. \%) of green crusts (EMPA analyses). 
reactions are capable of supplying sufficient energy for chemoorganotrophic growth of microbes.

In the context of this research, the record of microbial communities is compatible with the interpreted hydrothermal origin of the green laminated crusts. Modern microbialites occur abundantly in the vicinity of submarine hydrothermal vents, which are the source of nutrients for microbes. Microbes that precipitate iron compounds and other minerals have been described in such environments as hydrothermal chimneys, hydrothermal vents and deep-sea volcanoes (e.g., Juniper and Fouquet, 1988; Vanko et al., 1991; Ghiorse and Ehrlich, 1992; Mandernack and Tebo, 1993; Connell et al., 2009; Templeton et al., 2009; Reolid et al., 2011).

The low-temperature hydrothermal environment inferred for the origin of veins infilling the inter-pillow spaces is compatible with the presence of microbes. Precipitation of iron could be related to increasing $\mathrm{pH}$ and Eh created in the microenvironment around microbial clumps: oxidizing and alkaline conditions would have favoured the precipitation of $\mathrm{Fe}^{3+}$, whereas $\mathrm{CO}_{2}$ is reduced to form carbon organic compounds (carbohydrates). Microbial activity may promote glauconite formation working as a catalyzer, as well as the extracellular polymeric substances (EPS) serving as a specific trap for

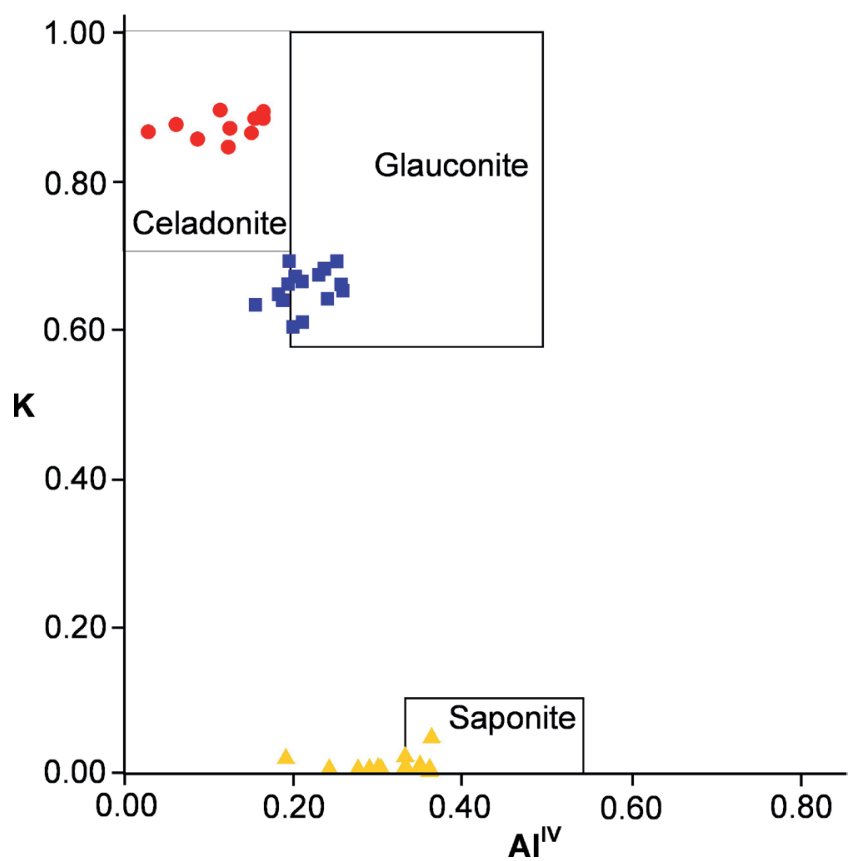

Fig. 16.- Composition of phyllosilicates of the studied crusts. Formulae per $\mathrm{O}_{10}(\mathrm{OH})_{2}$. Circles: celadonites, squares: glauconites and triangles: saponites. Based on a diagram proposed by Alt (1999).
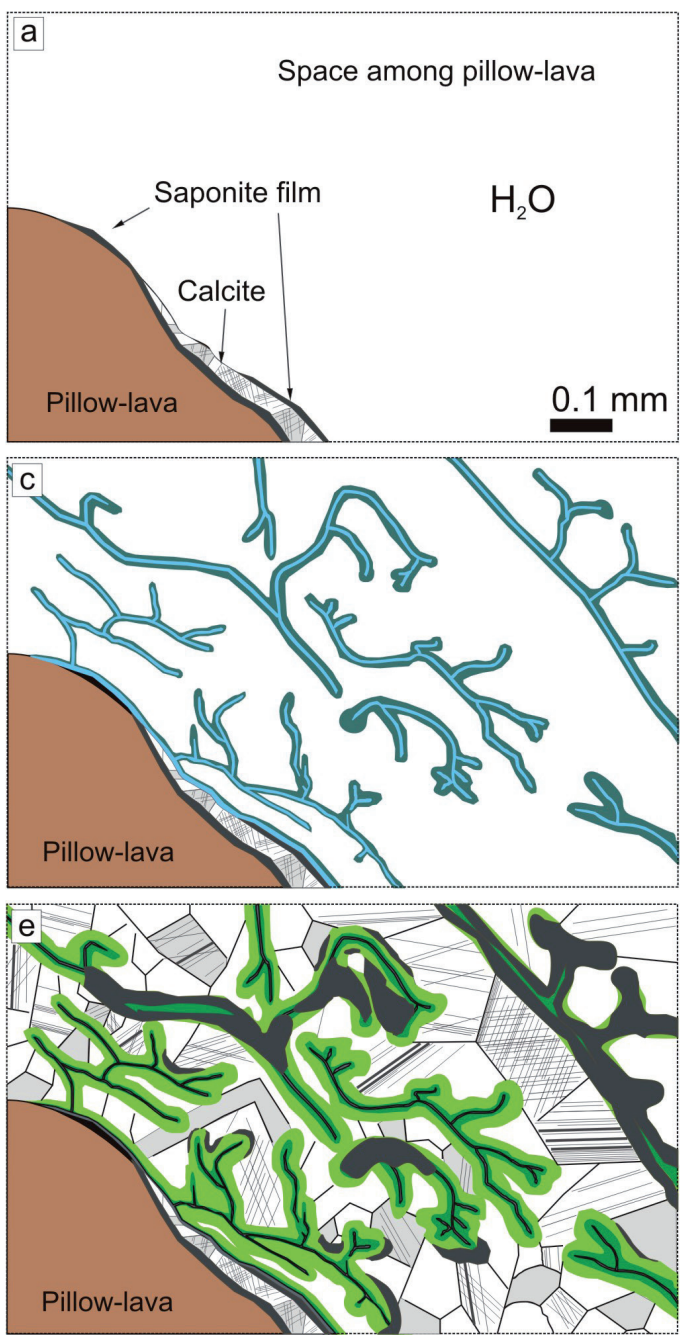
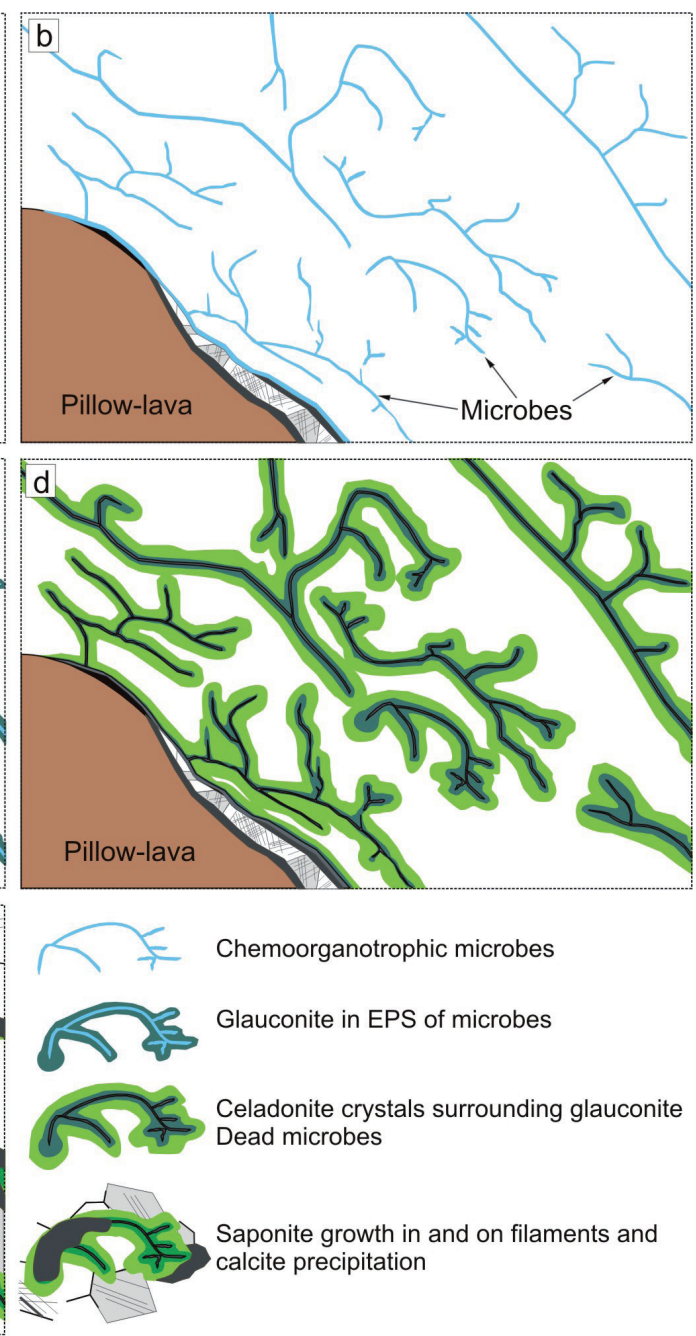

Fig. 17.- Different stages in the infilling of the spaces between pillow-lavas. a) A very thin sheet of saponite (black sheet) growth during a very preliminary stage of formation of the secondary minerals over the pillowlava walls. b) Chemoorganotrophic microbes growth under oxidizing conditions obtaining energy from alteration of pillow-lava in a semi-confined environment with sea-water circulation. c) Glauconite is accumulated in the extracellular polymeric substances (EPS) as by-products. d) Celadonite is formed in the external part of the filaments directly or as a result of maturation of glauconite in contact with the sea-water in intra-pillow spaces. e) Marine sediments have buried the volcanic pile and sea-water circulation is restricted, resulting in a confined/reducing environment with growth of calcite and quartz, and in some voids a second generation of saponite. 
$\mathrm{Fe}$ and $\mathrm{K}$. In the studied green laminated crusts, the existence of mucilaginous biofilms around the filaments and their role as a chelating compound secreted by microorganisms in the precipitation of glauconitic micas may be inferred by the occurrence of voids surrounded by glauconite reproducing the branching filamentous microstructures. Authigenesis occurred through the glauconite precursor precipitated on the EPS. The mineralisation of the microbial biofilms could have occurred simply as a result of passive attracting of $\mathrm{Fe}^{2+}$ ions from hydrothermal fluids to the negatively charged microbial EPS (e.g. Beveridge et al., 1997). At modern hydrothermal vents, the passive mineralisation is believed to constitute the most important process of microbe encrustation with iron (Konhauser, 1998). Whatever the source of $\mathrm{Fe}^{2+}$ (pillow-lava alteration or hydrothermal fluids), a rapid oxidation to $\mathrm{Fe}^{3+}$ during its nucleation on microbial surfaces is possible.

Celadonite (the most advanced step in the glauconitisation process of Odin and Matter, 1981) can be interpreted as (1) a later abiotic precipitation on filament surface, the inner glauconite being the nucleation site for subsequent growth of more complex authigenic celadonite, or (2) more external glauconite composing the coating of the filament after successive reactions of recrystallisation trapping more and more potassium (Fig. 15). The distribution of glauconite and celadonite, representing a Fe decreasing trend to the outer part of the filaments, agrees with $\mathrm{Fe}$-chemoorganotrophic processes for the precipitation of glauconite in the EPS, but passive mineralisation of EPS is also a potential mechanism.

The role of microbes in the genesis of glauconite has been pointed out previously in sedimentary environments (Geptner and Ivanovskaya, 2000; Zanin et al., 2004, 2006; Eder et al., 2007; Baldermann et al., 2013) and hydrothermal environments (Tazaki and Fyfe, 1992; Geptner et al., 2008). Tazaki and Fyfe (1992) reported celadonite and glauconite related to filamentous bacteria in the hydrothermal alteration of volcanic sandstones in deep-sea sediments from IzuBonin fore-arc (west Pacific Ocean). However, the cases described in the literature commonly concern green pellets, not laminated crusts. The laminated texture of these glauconitic crusts is congruent with the participation of microbes in the glauconite formation. Other examples from the Subbetic of laminated crusts and macro-oncoids composed by $\mathrm{Fe}-\mathrm{Mn}$ oxyhydroxides and phosphates have been previously interpreted as related to chemosynthetic microbial communities in marine environments (e.g. Martín-Algarra and Sánchez-Navas, 2000; Reolid and Nieto, 2010). Therefore, the laminated texture is congruent with the inferred microbial origin, and also comparable with calcareous stromatolites widely known in the geological record.

Another clay mineral commonly recorded in the low temperature hydrothermal alteration of basalts is nontronite, which has been described in the literature as genetically related to bacteria in marine white smoker chimneys from the Galapagos Spreading Center and Mariana Trough by Köhler et al. (1994).
Microendolithic microbes from Devonian basalts corresponding to filaments with a branching pattern, preserved as clay minerals chamosite/glauconite and illite/glauconite, were reported by Eickmann et al. (2009). These authors further observed an inner part of the filaments consisting of chamosite/glauconite surrounded by illite-glauconite. The main difference with respect to the examples from pillow-lavas from the Median Subbetic would be the epilithic behaviour of the inferred microbes.

\section{Conclusions}

The aim of this research was to analyse the secondary minerals composing veins and infilling spaces among pillow-lava bodies from the Jurassic of the Median Subbetic, mainly focused on the characterisation of green laminated crusts and clay minerals.

The mineralogy, geochemistry, and geometric relationships of the minerals infilling the spaces among pillow-lavas allowed us to recognise different stages in the growth of these mineralisations. Saponite and calcite are deposited in a very preliminary phase of the alteration process over the pillowlava surface, under moderate temperature. Glauconite and celadonite form later under oxydizing and cooler conditions due to the circulation of sea-water, and promoted by the activity of chemoorganotrophic microbes, or as passive mineralisation of the extracellular polymeric substances. Microbes benefited both the oxidizing conditions related to the input of sea-water as well as input of reduced hydrothermal fluids rich in metals (they proliferated in the boundary between both conditions).

Subsequently, the temperature increases progressively towards higher values as a consequence of burial promoted by marine sedimentation, which also contributes to reducing conditions. Microbial activity stopped. A new episode of saponite and calcite formation, in some veins with evidence of glauconitic mica consumption, takes place. Finally, calcite and quartz precipitate as the latest products on the voids among pillow-lava bodies, sometimes with incomplete infilling resulting in geodes.

\section{Acknowledgements}

This research was carried out with the financial support of Projects UJA/2011/12/17 (Universidad de Jaén), P11RNM-7408 (Junta de Andalucía), RYC-2009-04316 (Ramón y Cajal Program, Ministerio de Ciencia e Innovación + FSE) and CGL2011-30153-C02-01 (Spanish Ministry of Science and Innovation) as well as research groups RNM-200 and RNM-325. We are also grateful to A. Piedra, technician at the Laboratorio de Geología of the Universidad de Jaén, for preparation of thin sections. Prof. J.M. Molina (Univ. Jaén) helped with the literature concerning petrology and mineralogy of the Jurassic volcanic rocks of the Median Subbetic. The constructive remarks of Prof. Massimo D'Antonio (Uni- 
versità degli Studi di Napoli Federico II) improved the quality of this work. We are grateful to a native English speaker (Jean Louise Sanders) for reviewing the grammar.

\section{References}

Abad, I., Jiménez-Millán, J., Molina, J.M., Nieto, F., Vera, J.A. (2003): Anomalous reverse zoning of saponite and corrensite caused by contact metamorphism and hydrothermal alteration of marly rocks associated with subvolcanic bodies. Clays and Clay Minerals 51, $543-$ 554. doi:10.1346/CCMN.2003.0510508

Alt, J.C. (1999): Very low-grade hydrothermal metamorphism of basic igneous rocks. In: M. Frey, D. Robinson (eds.) Low-grade Metamorphism, Blackwell, Oxford, 169-201.

Alt, J.C., Lanord, C.F., Floyd, P.A., Castillo, P., Galy, A. (1992): Low temperature hydrothermal alteration of Jurassic oceanic crust, Site 801. Proceeding ODP Sci. Results 129, 415-427.

Amorosi, A. (1995): Glaucony and sequence stratigraphy: a conceptual framework of distribution in siliciclastic sequences. Journal of Sedimentary Research 65, 419-425. doi: 10.1306/D4268275-2B2611D7-8648000102C1865D

Andrews, A.J. (1980): Saponite and celadonite in layer 2 basalts DSDP Leg 37. Contributions to Mineralogy and Petrology 73, 323-340. doi:10.1007/BF00376627

Bach, W., Edwards, K.J. (2003): Iron and sulphide oxidation within the basaltic ocean crust: implications for chemolithoautotrophic microbial biomass production. Geochimica et Cosmochimica Acta 67, 3871-3887. doi:10.1016/S0016-7037(00)00304-1

Baker, L.L., Rembert, W.C., Sprenke, K.F., Strawn, D.G. (2012): Celadonite in continental flood basalts of the Columbia River Basalt Group. American Mineralogist 97, 1284-1290. doi:10.2138/am.2012.4129

Baldermann, A., Warr, L.N., Grathoff, G.H., Dietzel, M. (2013): The rate and mechanism of deep-sea glauconite formation at the Ivory Coast-Ghana Marginal Ridge. Clays and Clay Minerals 61, 258-276. doi:10.1346/CCMN.2013.0610307

Benz, M., Brune, A., Schink, B. (1998): Anaerobic and aerobic oxidation of ferrous iron at neutral $\mathrm{pH}$ by chemoheterotrophic nitrate-reducing bacteria. Archives of Microbiology 169, 159-165. doi:10.1007/ s002030050555

Beveridge, T.J., Makin, S.A., Kadurugamuwa, J.L., Li, Z.S. (1997): Interactions between biofilms and the environments. FEMS Microbiol Rev 20, 291-303. doi: 10.1111/j.1574-6976.1997.tb00315.x

Bornhold, B.D., Giresse, P. (1985): Glauconitic sediments on the continental shelf off Vancouver Island, British Columbia, Canada. Journal of Sedimentary Petrology 55, 653-664. doi: 10.1306/212F87AB2B24-11D7-8648000102C1865D

Buatier, M., Honnorez, J., Ehret, G. (1989): Fe-smectite-glauconite transition in hydrothermal green clays from the Galapagos Spreading Center. Clays and Clay Minerals 37, 532-541. doi:10.1346/ CCMN.1989.0370605

Buatier, M., Ouyang, K., Sánchez, J.P. (1993): Iron in hydrothermal clays from the Galapagos Spreading Centre Mounds: consequences for the clay transition mechanism. Clay Minerals 28, 641-655. doi: 10.1180/claymin.1993.028.4.11

Clauer, N., O’Neil, J.R., Honnorez, J., Buatier, M. (2011): ${ }^{87} \mathrm{Sr} /{ }^{86} \mathrm{Sr}$ and ${ }^{18} \mathrm{O} /{ }^{16} \mathrm{O}$ ratios of clays from a hydrothermal area near the Galapagos rift as records of origin, crystallization temperature and fluid composition. Marine Geology 288, 32-42. doi: 10.1016/j.margeo.2011.07.003

Clayton, T., Pearce, R.B. (2000): Alteration mineralogy of Cretaceous basalt from ODP Site 1001, Leg 165 (Caribbean Sea). Clay Minerals 35, 719-733. doi:10.1180/000985500547043

Cliff, G., Lorimer, G.W. (1975): The quantitative analyses of thin specimens. Journal of Microscopy 103, 203-207. doi:10.1111/j.1365-2818.1975.tb03895.x

Comas, M.C., Puga, E., Bargossi, G.M., Morten, L., Rossi, P.L. (1986): Paleogeography, sedimentation and volcanism of the Central Subbetic Zone, Betic Cordilleras, Southeastern Spain. Neues Jahrbuch für Geologie und Paläontologie Monatshefte 7, 385-404.

Connell, L., Barret, A., Templeton, A., Staudigel, H. (2009): Fungal diversity associated with Active Deep Sea Volcano: Vailulu'u Seamount, Samoa. Geomicrobiology Journal 26, 597-605. doi:10.1080/01490450903316174

D’Antonio, M., Kristensen, M.B. (2005): Hydrothermal alteration of oceanic crust in the West Philippine Sea Basin (Ocean Drilling Program Leg 195, Site 1201): inferences from a mineral chemistry investigation. Mineralogy and Petrology 83, 87-112. doi:10.1007/ s00710-004-0060-6

Delmont, P. (1985): Smectites et produtis d'altération des basaltes tertiaires des iles Faeroe (Atlantique Nord Est). Genèse, évolution et contribution à la sédimentation océanique. PhD Thesis Université de Bordeaux I, $490 \mathrm{p}$.

Desprairies, A., Bonnot, C., Jehanno, C., Vernhet, S., Joron, J.L. (1984): Mineralogy and geochemistry of alteration products in Leg 81 basalts. Initial Report DSDP 81, U.S. Govt. Print. Off, Washington, pp. 733-742.

Desprairies, A., Tremblay, P., Laloy, C. (1989): Secondary mineral assemblages in a volcanic sequence drilled during ODP LEG 104 in the Norwegian Sea. Proceedings of the Ocean Drilling Program, Scientific results 104, 397-409.

Eder, V., Martín-Algarra, A., Sánchez-Navas, A., Zanin, Y.N., Zamirailova, A.G., Lebedevs, Y.N. (2007): Depositional controls on glaucony texture and composition, Upper Jurassic, West Siberian Basin. Sedimentology 54, 1365-1387. doi:10.1111/j.1365-3091.2007.00885.x.

Edwards, K.J., Bach, W., McCollom, T.M. (2005): Geomicrobiology in oceanography: microbe-mineral interactions at and below the seafloor. Trends in Microbiology 13, 449-456.

Eickmann, B., Bach, W., Kiel, S., Reitner, J., Peckmann, J. (2009): Evidence for cryptoendolithic life in Devonian pillow basalts of Variscan orogens, Germany. Palaeogeography, Palaeoclimatology, Palaeoecology 283, 120-125. doi: 10.1016/j.palaeo.2009.09.006

Fischer, H. (1990): Glauconite formation: discussion of the terms authigenic, perigenic, allogenic, and meta-allogenic. Eclogae Geologicae Helvetiae 83, 1-6.

Geptner, A.R., Ivanovskaya, T.A. (2000): Glauconite from Lower Cretaceous marine terrigenous rocks of England: a concept of biochemogenic origin. Lithology and Mineral Resources 35, 487-499.

Geptner, A.R., Ivanovskaya, T.A., Pokrovskaya, E.V., Kuralenko, N.P. (2008): Glauconite from Paleogene volcano-terrigenous rocks in Western Kamchatka. Lithology and Mineral Resources 43, 228-249. doi:10.1134/S0024490208030036

Ghiorse, W.C., Ehrlich, H.L. (1992): Microbial biomineralization of iron and manganese. In: H.C.W. Skinner, R.W. Fitspatrick RW (eds.) Biomineralization. Processes of Iron and Manganese Modern and Ancient Environments. Catena supplements 21, 75-99.

Henry, C., Boisson, J.Y., Bouchet, A., Meunier, A. (2007): Thermally induced mineral and chemical transformations in calcareous mudstones around a basaltic dyke (Perthus Pass, southern Massif Central, France). Possible implications as a natural analogue of nuclear waste disposal. Clay Minerals 42, 213-231. doi:10.1180/claymin.2007.042.2.07

Ionescu, C., Hoeck, V., Pop, D. (2006): Sea-water alteration of mesozoic basaltic rocks from the Transylvanian Depression Basement (Romania). Proceedings of XVIII Congress CBGA, pp 236-239.

Jarrar, G., Amireh, B., Zachmann, D. (2000): The major, trace and rare element geochemistry of glauconites from the early Cretaceous Kurnub Group of Jordan. Geochemical Journal 34, 207-222.

Jiménez-Millán, J., Molina, J.M., Nieto, F., Nieto, L., Ruiz-Ortiz, P.A. (1998): Glauconite and phosphate peloids in Mesozoic carbonate sediments (eastern Subbetic Zone, Betic Cordilleras, SE Spain). Clay 
Minerals 33, 547-559. doi: 10.1180/000985598545886.

Jiménez-Millán, J., Abad, I., Nieto, F. (2007): Gobbinsite and garronite assemblage produced by the intrusion and alteration of subvolcanic bodies (External Zone, Betic Codillera). Seminarios de la Sociedad Española de Mineralogía 3, p. 104.

Jiménez-Millán, J., Abad, I., Nieto, F. (2008): Contrasting alteration processes in hydrothermally altered dolerites from the Betic Cordillera, Spain. Clay Minerals 43, 267-280. doi:10.1180/claymin.2008.043.2.09

Juniper, S.K., Bouquet, Y. (1988): Filaments iron-silica deposits from modern and ancient hydrothermal sites. The Canadian Mineralogist 26, 859-869.

Kemp, S.J., Rochelle, C.A., Merriman, R.J.(2005): Back-reacted saponite in Jurassic mudstones and limestones introduced by a Tertiary sill, Isle of Skye. Clay Minerals 40, 263-282. doi:10.1180/0009855054030171

Köhler, B., Singer, A., Stoffers, P. (1994): Biogenic nontronite from marine white smoker chimneys. Clays and Clay Minerals 42, 689-701. doi:10.1346/CCMN.1994.0420605

Konhauser, K.O. (1998): Diversity of bacterial iron mineralization. Earth-Science Review 43, 91-121. doi:10.1016/S00128252(97)00036-6

Mandernack, K.W., Tebo, B.M. (1993): Manganese scavenging and oxidation at hydrothermal vents and in vent plumes. Geochimica et Cosmochimica Acta 57, 3907-3923. doi:10.1016/0016-7037(93)90343-U

Martín-Algarra, A., Sánchez-Navas, A. (2000): Bacterially mediated authigenesis in Mesozoic stromatolites from condensed pelagic sediments (Betic Cordillera, Southern Spain). In: Marine Authigenesis: from global to microbial. Tulsa, Society for Sedimentary Geology (SEPM) Special Publication 66, 499-525.

Millot, G. (1964): Géologie des Argiles. Masson, Paris, 499 p

Morata, D.A., Puga, E., Demant, A., Aguirre, L. (1996): Evolución petrogenética del magmatismo básico mesozoico en las Zonas Externas de las Cordilleras Béticas (S. España). Geogaceta 20, 576-578.

Odin, G.S., Fullagar, P.D. (1988): Geological significance of the glaucony facies. In: G.S. Odin (ed.) Green Marine Clays. Elsevier. Developments in Sedimentology 45, 295-332.

Odin, G.S., Letolle, R. (1980): Glauconitization and phosphatization environments: a tentative comparison. Society for Sedimentary Geology (SEPM) Special Publication 29, 227-237.

Odin, G.S., Matter, A. (1981): De glauconiarum origine. Sedimentology 28, 611-641. doi:10.1111/j.1365-3091.1981.tb01925.x

Odin, G.S., Desprairies, A., Fullagar, P.D., Bellon, H., Decarreau, A., Frohlich, F., Zelvelder, M. (1988): Nature and geological significance of celadonite. In: Odin, G.S. (ed.) Green Marine Clays. Elsevier. Developments in Sedimentology 45, 337-398.

Porrenga, D.H. (1967): Glauconite and chamosite as depth indicators in the marine environment. Marine Geology 5, 495-501. doi:10.1016/0025-3227(67)90056-4

Portugal, M., Morata, D.A., Puga, E., Demant, A., Aguirre, L. (1995): Evolución geoquímica y temporal del magmatismo básico mesozoico en las Zonas Externas de las Cordilleras Béticas. Estudios Geológicos 51, 109-118. doi:10.3989/egeol.95513-4

Pouchou, J.L., Pichoir, F. (1985): "PAP” (f) (r) (t) procedure for improved quantitative microanalysis. In: J.T. Armstrong (ed.) $\mathrm{Mi}$ crobeam Analysis, San Francisco Press, San Francisco, 104 pp.

Puga, E., van de Fliert, J.R., Torres-Roldán, R.L., Sanz de Galdeano, C. (1988): Attempts of the whole-rock K/Ar dating of Mesozoic volcanic and hypabissal igneous rocks from the central Subbetic (Southern Spain): a case of differential argon loss related to very lowgrade metamorphism. Estudios Geológicos 44, 47-59. doi:10.3989/ egeol.88441-2

Puga, E., Portugal, M., Díaz de Federico, A., Bargossi, G.M., Morten, L. (1989): The evolution of the magmatism in the External Zones of the Betic Cordillera during the Mesozoic. Geodinamica Acta 3, 253-266.
Renac, C., Kyser, K., Bowden, P., Moine, B., Cottin, J.Y. (2010): Hydrothermal fluid interaction in basaltic lava units, Kerguelen Archipelago (SW Indian Ocean). European Journal of Mineralogy 22, 215-234. doi:10.1127/0935-1221/2009/0022-1993

Reolid, M., El Kadiri, K., Abad, I., Olóriz, F., Jiménez-Millán, J. (2011): Jurassic microbial communities in hydrothermal manganese crust of the Rifian Calcareous Chain, Northern Morocco. Sedimentary Geology 233, 159-172. doi:10.1016/j.sedgeo.2010.11.008

Reolid, M., Nieto, L.M. (2010): Jurassic Fe-Mn macro-oncoids from pelagic swells of the External Subbetic (Spain): evidence of microbial origin. Geologica Acta 8, 151-168. doi:10.1344/105.000001525

Rieder, M., Cavazzini, G., D’Yakonov, Y.S., Frank-Lamenetskii, V.A., Gottardi, G., Guggenheim, S., Koval, P.V., Müller, G., Neiva, A.M.R., Radoslovich, E.W., Robert, J.L., Sassi, F.P., Takeda, H., Weiss, Z., Wones, D.R. (1998): Nomenclature of the micas. The Canadian Mineralogist 36, 905-912.

Sánchez-Navas, A., Martín-Algarra, A., Eder, V., Reddy, B.J., Nieto, F., Zanin, Y.N. (2008): Color, mineralogy and composition of Upper Jurassic west Siberian glauconite: useful indicators of paleoenvironment. The Canadian Mineralogist 46:1249-1268. doi:10.3749/can$\min .46 .5 .00$

Santelli, C.M. (2009): Life in the deep sea. Nature Geoscience 2, 825826. doi:10.1038/ngeo711

Santelli, C.M., Orcutt, B.N., Banning, E., Bach, W., Moyer, C.L., Sogin, M.L., Staudigel, H., Edwards, K.J. (2008): Abundance and diversity of microbial life in ocean crust. Nature 453, 653-656. doi:10.1038/ nature06899

Staudigel, M., Gillis, K., Duncan, R. (1986): K-Ar and Rb-Sr ages of celadonites from the Troodos ophiolite, Cyprus. Geology 14, 72-75. doi: 10.1130/0091-7613(1986)14

Stackes, D.S., O’Neil, J.R. (1982): Mineralogy and stable isotope geochemistry of hydrothermaly altered oceanic rocks. Earth and Planetary Science Letters 57, 285-304. doi:10.1016/0012-821X(82)90151-0

Taylor, S.R., McLennan, S.M. (1985): The Continental Crust: its Composition and Evolution. Blackwell Scientific Publications, Oxford. 328 p.

Tazaki, K., Fyfe, W. (1992): Microbial green marine clay from IzuBonin (west pacific) deep-sea sediments. Chemical Geology 102, 105-118. doi:10.1016/0009-2541(92)90149-Y

Templeton, A.S., Knowles, E.J., Eldridge, D.L., Arey, B.W., Dohnalkova, A.C., Webb, S.M., Bailey, B.E., Tebo, B.M., Staudigel, H. (2009): A seafloor microbial biome hosted within incipient ferromanganese crusts. Nature Geosciences 2, 872-876. doi:10.1038/ngeo696

Tóth, E., Weiszburg, T.G., Jeffries, T., Williams, C.T., Bartha, A., Bertalan, E., Cora, I. (2010): Submicroscopic accessory minerals overprinting clay mineral REE patterns (celadonite-glauconite group examples). Chemical Geology 269, 312-328. doi:10.1016/j.chemgeo.2009.10.006

Vanko, D.A., Milby, B.J., Heinzquith, S.W. (1991): Massive sulphides with fluid-inclusion-bearing quartz from a young seamount on the East Pacific Rise. The Canadian Mineralogist 29, 453-460.

Vera, J.A., Molina, J.M., Montero, P., Bea, F. (1997): Jurassic guyots on the Southern Iberian Continental Margin: a model of isolated carbonate platforms on volcanic submarine edifices. Terra Nova 9, 163-166. doi:10.1046/j.1365-3121.1997.d01-22.x

Wigley, R., Compton, J.S. (2007): Oligocene to Holocene glauconitephosphorite grains from the Head of the Cape canyon on the western margin of South Africa. Deep-Sea Research II 54, 1375-1395. doi:10.1016/j.dsr2.2007.04.004

Zanin, Y.N., Eder, V.G., Zamirailova, A.G. (2004): Bacterial forms in glauconites from Upper Jurassic deposits of the West Siberian Plate. Russian Geology and Geophysics 45, 774-777

Zanin, Y.N., Eder, V.G., Zamirailova, A.G. (2006): Mn-carbonates, glauconites and phosphorites in the Upper Jurassic Georgiev Formation of the West Siberian marine basin. Geophysical Research Abstracts 8, 000271. 